\title{
Urban Water Governance and Learning-Time for More Systemic Approaches?
}

\author{
Åse Johannessen $1,2, *(1)$ and Erik Mostert ${ }^{2}$ (]) \\ 1 Division of Risk Management and Societal Safety, Lund University, P.O. Box 118, 22100 Lund, Sweden \\ 2 Department of Water Management, Delft University of Technology (TU Delft), Stevinweg 1, \\ 2628 CN Delft, The Netherlands; E.Mostert@tudelft.nl \\ * Correspondence: ase.johannessen@gmail.com
}

Received: 23 June 2020; Accepted: 21 August 2020; Published: 25 August 2020

\begin{abstract}
Social learning, especially triple-loop social learning involving institutional and governance changes, has great potential to address urban water issues such as flooding, drought, and pollution. It facilitates urban transition and the adoption of more systemic approaches and innovations. Social learning in water governance is a growing field, but the triple-loop learning concept remains vague and underexplored. Additionally, the focus is often on how social learning can contribute to progress with little attention being paid to barriers to learning. The aim of this paper is to increase understanding of triple-loop social learning to improve the "learning infrastructure". It investigates key learning barriers for realizing green (livable) and adaptive cities in Malmö and Gothenburg, Sweden. Integration of nature-based solutions in spatial planning and development of these cities has been slow. The results found three types of barriers contributing to this: systemic (disconnecting parts with the whole); opacity (reducing communication between error detection and correction); and process-related (reducing the adoption of innovations). The paper contributes to understanding the social learning barriers for implementing planning. These insights could help overcome "adaptation inertia" and speed up policy learning towards sustainability and resilience.
\end{abstract}

Keywords: social learning; urban water governance; climate adaptation

\section{Introduction}

Urban areas are complex, dynamic, and interconnected systems that need to cope and adapt to a changing world. A lack of attention to governing whole systems and their dynamics has been argued to result in unsustainable practices and eroding systems resilience [1,2]. Additionally, cities grow fast, and in combination with a changing climate, there emerges a cocktail of water-related risks, e.g., floods, storms, drought, and pollution [3-5]. Good water governance in urban areas therefore requires continuous learning by policy-makers, managers, and other stakeholders [6-10]. However, changes in urban water governance are often incidental [11] and slow in coming [12-19].

An increasing number of scholars and practitioners are turning towards social learning to provide timely, adaptive, systemic, and transformative water governance [10,19-21]. Social learning generally refers to changes in collective understanding that result from the exchange of knowledge and experiences and lead to changes in practice [22-24]. However, the concept needs more clarity and precision [10]. This relates specifically to "triple-loop learning" [20,25]. Triple-loop learning questions the institutional and governance context or "learning infrastructure", which includes the fundamental values and norms that guide human thinking, acting, and learning [26]. Especially in a dynamic and evolving society, it is important to continuously question the learning infrastructure. It determines whether social learning contributes to sustainable and resilient policy outcomes-addressing whole 
systems—or just provides temporary quick fixes [1,27]. However, most studies pay little attention to potential learning barriers to sustainable solutions [28].

This paper aims to increase understanding of social learning, particularly the social learning infrastructure. It investigates the barriers to learning in urban water planning and development in Gothenburg and Malmö, Sweden. These cities are growing by means of densification, thus preventing urban sprawl but also threatening livability and potentially increasing water-related risks [29-32]. Nature-based solutions, e.g., green areas for storing flood water, could mitigate flood risk, reduce pollution, lower peak temperatures, and make the area more attractive [14,33-37]. To adopt nature-based solutions, urban governments and other stakeholders need to change their approach to urban development. This requires social learning through knowledge co-production, collaboration, and collective action of people with different working paradigms [6,9,19-22,38-49]. Understanding social learning barriers in this context could not only inform social learning theory, but also help the design of innovation and collective action strategies for urban areas [11,44].

In the next section we introduce the theoretical framework, based largely on organizational learning [50-54] and collective action [55-58]. Then, the two cases and the methodology used are introduced. Next, the results are presented. The paper concludes by discussing implications for social learning theory and how the findings can inform a strategy for systemic and transformative learning and management.

\section{Analytical Framework-Social Learning}

Social learning is concerned with changes in both collective understanding and practice [22-24]. It is an experimental, adaptive, and iterative process, with different rounds of action and reflection. As used here, it is epistemologically rooted in organizational management theory, where learning has been defined as "the detection and correction of errors, and error as any feature of knowledge or of knowing that makes action ineffective" [50] (p. 365); cf. the notion of "learning by doing" in adaptive management theory [9,59-62]. Error is a mismatch, a condition of learning, and matching a second condition of learning [50]. For learning to happen, the effects of actions need to be monitored and communicated to actors involved in decision making (error detection), who in turn need to be willing and able to act upon this information and address any issues (error correction) (Figure 1).

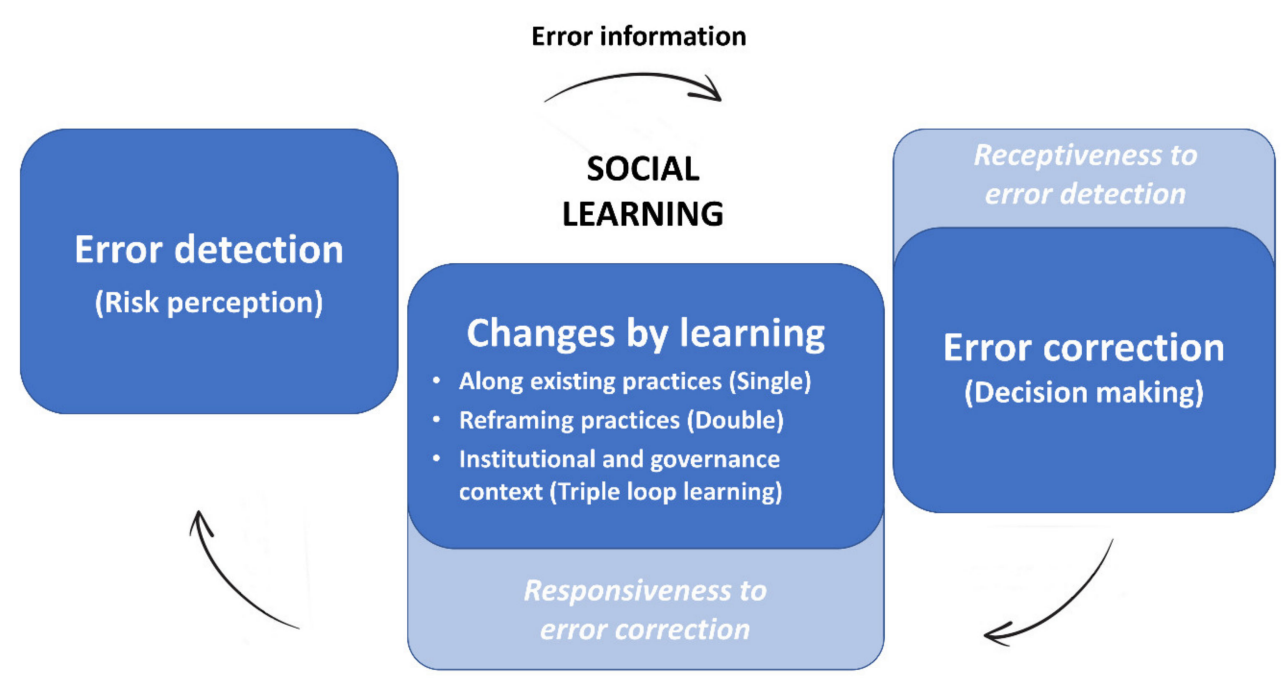

Figure 1. Social learning as interactive error detection and correction, with learning outcomes at different "depths" (single, double, triple-loop learning; adapted by authors, based on [50]).

Learning can be made more effective by producing valid information (error information) for the decision makers to use to monitor the effectiveness of their decisions. This is facilitated by interpersonal, group, intergroup, and bureaucratic factors [50]. Here, organizational norms are a strong inhibiting 
factor for learning, where challenging current approaches is often not appreciated and rewarded to the degree that errors may be hidden by the actors [51]. Learning can also be made more effective by increasing the responsiveness to error correction [50] (see Figure 1). Additionally, several factors may reduce the motivation to engage in social learning, e.g., limited capacity, skills, time, and transaction costs in changing governance and institutions [63]. Thus, barriers to learning and collective action are hard to overcome, and instead, change often needs triggering by crises and failures $[20,64]$.

Learning can involve both straightforward and more fundamental issues [26]. Single-loop learning occurs "whenever an error is detected and corrected without questioning the underlying frames of references or guiding assumptions of the system" [52] (p. 68). Double-loop learning questions these frames and assumptions and involves reframing [54]. This is more likely to occur in situations where knowledge is co-produced through multiple perspectives [55]. Pahl-Wostl (2009) argues that double-loop learning may require so called "triple-loop learning". The institutional and governance context determines learning by constraining actors' frames of reference, or limiting their rationality and behavior, by the information it provides $[65,66]$. Triple-loop learning questions this system and its fundamental values and norms that have produced and support the frames of references and guiding assumptions [26]. Learners not only engage in reframing, as in double-loop learning, but also develop new processes or methodologies for reframing [67]. This involves institutionalizing: "the process of embedding learning that has occurred by individuals and groups into the organization, [ ... ] [which] includes systems, structures, procedures, and strategy" [68] (p. 525). Institutionalization is a continuous process, but there can be significant discontinuities, e.g., when formal institutions such as Acts are changed. In practice, it is often difficult to distinguish between double and triple-loop learning, as informal institutional change may remain implicit $[20,25]$. In relation to water management, error detection is involved with perceiving risks to the water-environment system, analyzing, and presenting the risks. Error correction is represented by decision making that may (or may not) take action to avoid, reduce, or prepare for the risks. (Figure 2). Depending on the depth of error detection and correction, the system is adapted at different levels [69].

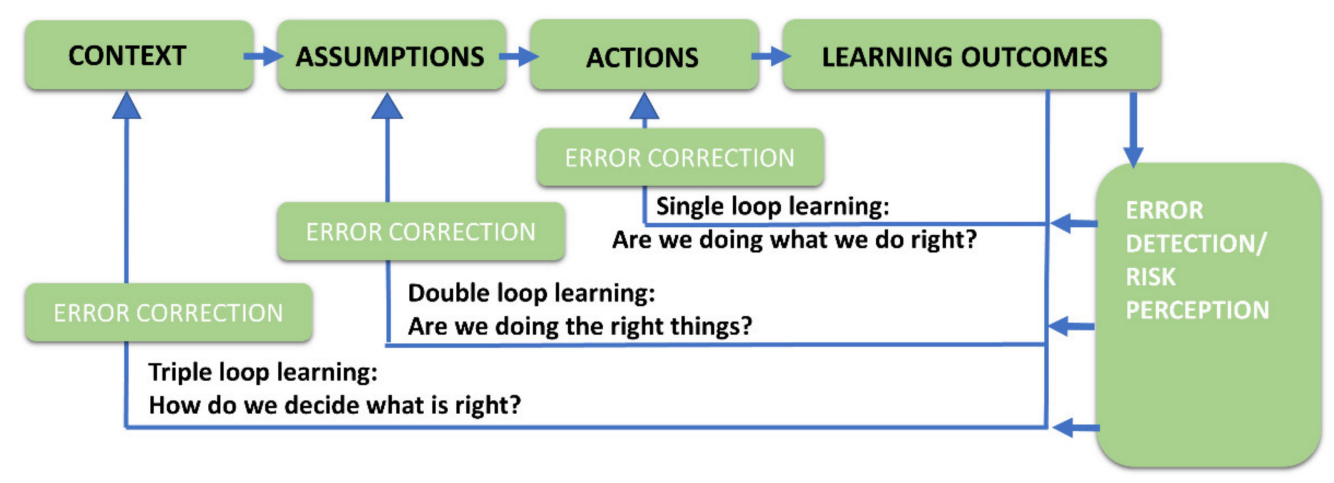

Figure 2. The three loops of learning [54] adapted to include risk perception and critical reflection and error correction [69].

The most interesting learning for systems change is triple-loop and related double-loop learning. To emphasize the systemic character of social learning of interconnected elements in governance, we use the concept of the urban "learning infrastructure system" as another term for triple-loop learning. This paper studies the flaws, or barriers, in this system. Ideally, the learning infrastructure captures the complex interconnected causes and effects in urban areas to provide fullness of learning, including communication, coordination, and decision making [70]. Here, the basic assumption is that social learning supports better outcomes [71]. This is not always the case [27] and this could be explained by flaws in the urban learning infrastructure, with inadequacies in error detection and correction affecting the behavior and ultimately the identity of the system [72]. 
The focus here is on the process of strategizing, spatial planning, implementation, and management by the urban water system that includes its actors and stakeholders $[39,73]$. Resilient and sustainable outcomes of such a process require the interaction of a diverse set of formal and informal actors and institutions nested at multiple levels and hierarchies [9] (Figure 3). From these interactions, we have identified social learning barriers between or within groups [74].

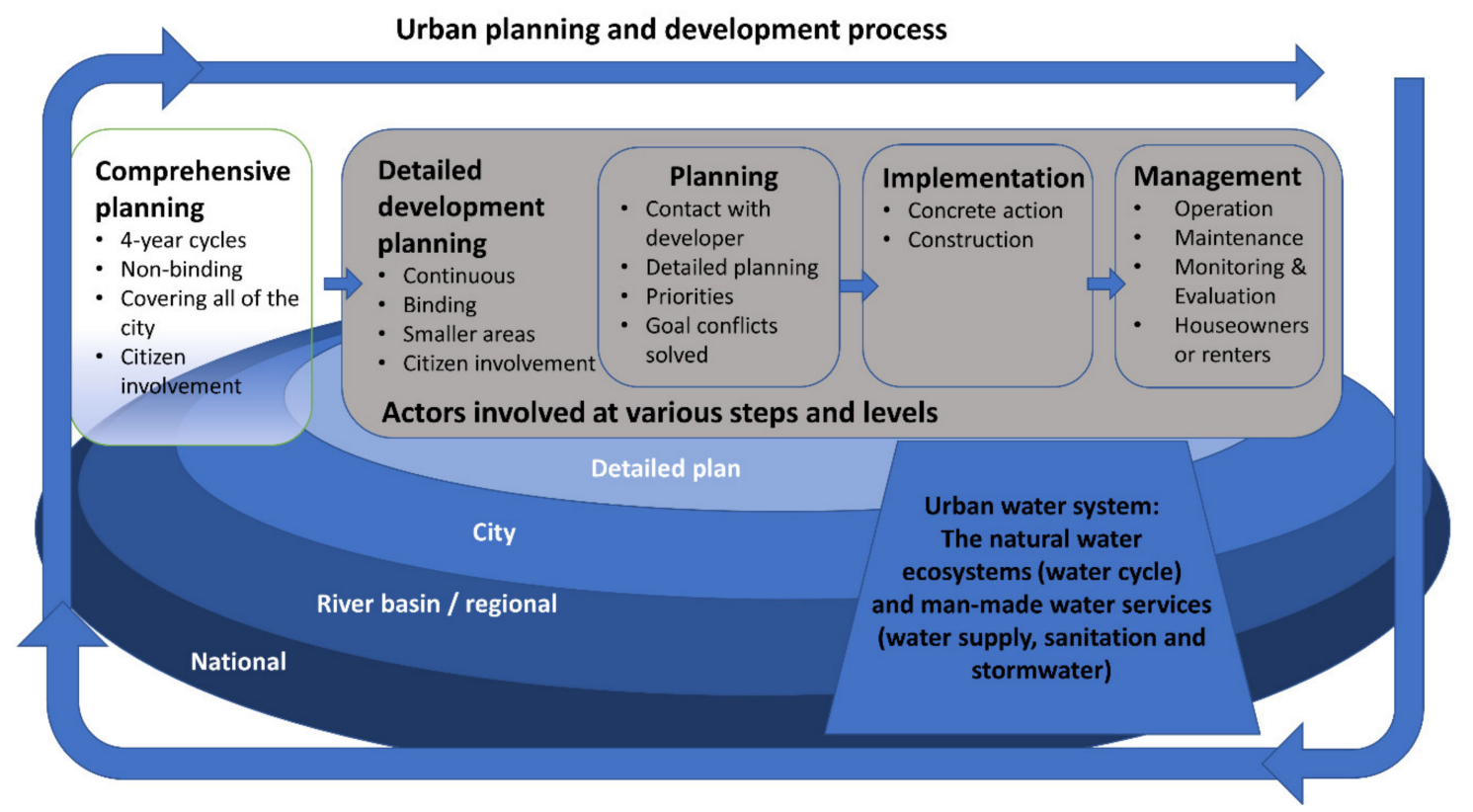

Figure 3. The system under study: the urban planning and development process, including its actors, and the urban water system at various levels. Adapted after [73].

\section{Methods}

\subsection{Research Design}

The research design applied here is a multiple case study with two cases: urban planning and the decision-making process related to critical water issues in Malmö and Gothenburg. It attempts to develop a comprehensive understanding of a phenomenon and develop related theory [75]. The similar or contrasting results across the two cases will help formulate more general findings [76]. The actors' own perspectives and experiences are central because the important reality that can explain action is what the actors perceive it to be [77].

The cases were selected to provide critical insights from urban areas in the forefront of sustainable governance, climate adaptation, and densification. Sweden ranks fifth globally on the Environmental Performance Index [78]; Gothenburg and Malmö are Sweden's second and third largest cities. Thus, any findings on failures are most likely to be valid for all, or a large range of cases, making it a critical case [79].

\subsection{Data}

Semi-structured interviews were held, using an interview guide (see Appendix A), which was adapted to the natural flow of respondent's answers [77]. Thirty interviewees were selected through purposeful and snowball sampling, to ensure they represented all relevant stakes [80]. Interviewees included mainly national (2) and regional planners (5), city politicians (5), city planners (11) including three working at utilities, private sector actors (4), and experts and scientists (3) (Appendix B).

All interviewees were promised confidentiality and gave informed consent. The interviews lasted about $60 \mathrm{~min}$ on average and were conducted mainly face-to-face in June 2018 (Malmö) and November 2018 (Gothenburg and nationally), complemented until March 2019 by telephone interviews. 
All interviews were digitally recorded and later transcribed. Scientific and grey documents from the cities (comprehensive planning documents, strategies, etc.) were used as complementary data. See Supplementary Materials for additional interview responses.

\subsection{Data Analysis}

Data were analyzed using coding, following a grounded theory approach [81]. First, all data related to error detection or error correction were selected, using the theoretical framework presented in Section 2 [82]. Concerning error detection, statements on phenomena that hid or prevented information from reaching decision making were selected. Concerning error correction, statements related to decision making were selected. Secondly, an initial set of themes and categories was developed and applied to this material ("open coding": [81]). The first results were then sorted, identifying patterns and interpreting findings. In this step, codes were grouped into higher-level categories ("selective coding"), e.g., financial, institutional, and working culture. Then, these categories were linked to each other ("theoretical coding; [82]). This step also involved document analysis and comparing the findings that emerged from the data with existing studies from Sweden and other countries [82,83].

\subsection{Case Studies}

Gothenburg (579,281 inhabitants) and Malmö (344,166 inhabitants) are the second and third largest cities in Sweden [84]. They are critical for investigating barriers to social learning concerning sustainable and resilient water governance and management for several reasons. Firstly, they are at risk of increasing water-related hazards, e.g., rising sea levels, pluvial (rain) flooding, and fluvial (river) flooding. However, only Malmö has experienced a major extreme pluvial flooding in recent years (2014). This may have affected social learning on flood management [85]. Secondly, both cities aim for densification to address the housing shortage [86] and preserve agricultural land [14]. Moreover, both cities include sustainability and nature-based solutions in their official strategies to address water-related hazards [87-90]. Green areas already make up c. $64 \%$ of the total urban land area in Gothenburg and 46\% in Malmö [91]. Thirdly, resources and knowledge are plentiful, and in many respects, the cities offer many best practices. Fourthly, both cities are attractive for real estate developers. This means they can impose more demands than less attractive municipalities can.

\subsection{Land Use Planning, Implementation, and Management Process}

In Sweden, municipalities have primary responsibility for urban planning and development, including water and sanitation services [92] (ch. 1, 2 §). They are required to have an up-to-date comprehensive plan (CP) [92] (ch. 3, 1 §). Following a broad consultation process, the CP should indicate the intended use of land and water areas; how the built environment should be used, developed, and maintained; what other public interests should be considered; and how national interests and environmental norms and goals will be met [92] (ch. 3, 2-18 §). Although the CP is not legally binding [92] (ch. 3, 3 §), it is meant to guide detailed development plans (DPPs), coordinated by the city planning office, and permits that are legally binding and regulate the exploitation in more detail [92] (ch. 4).

In Gothenburg the current CP was adopted in 2009, and a new CP is planned to be adopted in 2021. Three groups of activities have been identified as part of climate change adaptation: (1) elevating the quay, (2) building storm surge barriers, and (3) addressing the flood risk on land [93]. In Malmö, the current CP was approved in 2014. Malmö city has a history as a forerunner in stormwater management ("Sustainable urban drainage systems" (SUDS)), initially thanks to a pioneering drainage engineer [94]. Therefore, in Malmö, there are several SUDS initiatives [95] that were effective for handling the extreme rainfall in 2014 [96]. 


\subsection{Role of Regional Level}

Sweden is a decentralized country with limited planning at national and regional levels. Municipalities have a "planning monopoly", including spatial planning and other main areas of concern to inhabitants. The national level has some influence on spatial planning, e.g., it has a supervisory and advisory role via county administration boards (CABs). CABs can, for example, express views on $\mathrm{CPs}$, but the municipalities determine whether to take account of those views. When a municipality develops a DDP, it also has to consult with the $\mathrm{CAB}$, which can intervene on issues that concern national or intermunicipal interests, environmental quality standards, health and safety, and the risk of hazards such as floods or erosion [92] (ch. 11, 10-11 §, 15 §). For example, CABs apply the National Board of Housing, Building, and Planning guidelines that recommend new developments should cope with a 100-year rainfall event $[97,98]$.

Other regional bodies include the regional council, responsible for health care, regional development, infrastructure planning, public transport, and culture. At the sub-regional level (e.g., the Scania region for Malmö and Väst (west) region for Gothenburg), several municipalities have formed an association to cooperate on, for example, planning and climate adaptation [99].

\section{Results}

Here we will describe error detection and correction in the two cities (Sections 4.1 and 4.2) as well as the factors influencing error detection and correction (Sections 4.3 and 4.4). A summary of the factors is provided at the end in Figure 4 and Appendix C.

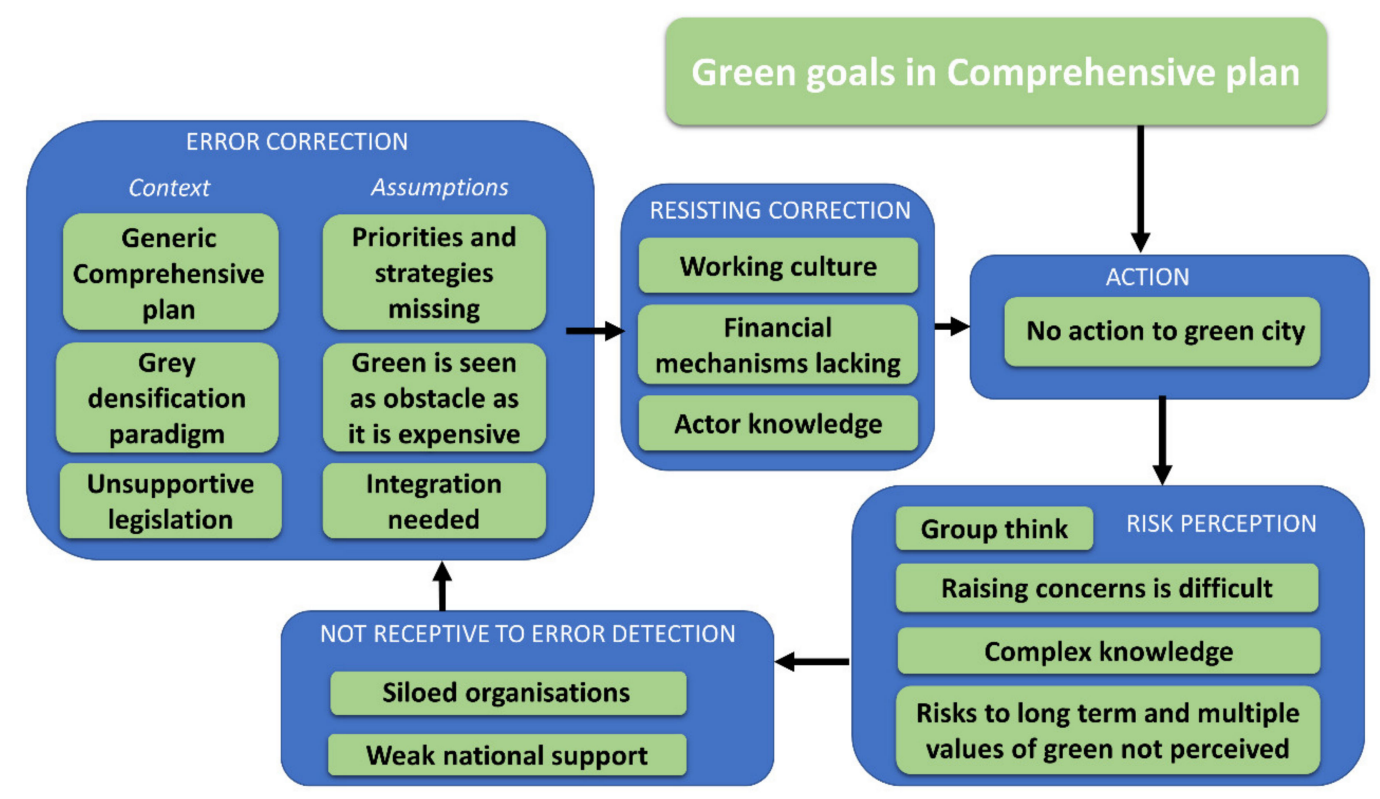

Figure 4. A summary of the multiple social learning barriers, described in more in detail in Annex C, for realiszing green goals in the comprehensive plan as mapped on to the analytical framework (figure adapted from Figures 1 and 2 by the authors).

\subsection{Error Detection}

The identified barriers to error detection are related to planning (Section 4.1.1), financing (Section 4.1.2), the densification mantra (Section 4.1.3), and knowledge building (Section 4.1.4).

\subsubsection{Water Planning at the Right Level}

Gothenburg and Malmö both have ambitious plans for water management, but their approaches differ. Gothenburg has a vision to be "the world's best city when it rains" [100] and has developed more planning materials (M7). For example, it has developed a "thematic plan" for water management, 
which complements the CP by providing detailed guidance on how a sustainable and robust city should be achieved. This plan gives generic requirements guidelines for DDPs that, if followed, increase the likelihood they are approved. Additionally, Gothenburg is the first Swedish city to have a "structural plan" for floods, based on a hydrological model managed by the Department of Sustainable Waste and Water. Learning from Copenhagen, Gothenburg is also developing "action plans" for the sub river basins, which also balance other interests with water [101].

Malmö used to have a thematic plan for water management [102], but since 2017, its main strategies and guidelines have been integrated into the CP [88]. Since 2017, water service company VA Syd has spearheaded an initiative for nature-based solutions in stormwater management ("Together we make space for water"). Malmö does not have structural plans, but the city's internal working processes aim to consider flood risk in individual DDPs. This is assisted by a water planner, who also keeps track of the effect of DDPs peak flows (M6; M9; M10). This process has grown organically in the recent years in the municipal planning offices because of awareness raising. The water planner can, if involved early, coordinate the effects of several DDPs, e.g., planning for a retention area upstream in public green spaces (M6).

Only recently has urban development planning in both cities developed an overview of the impact of land use changes at river basin level on water flows. For many years, the increase of hard surfaces contributed to the creeping increase of flood risk in "urban rivers". For example, in Gothenburg, an urban river has built up to such a degree that models predict the risk downstream of a meter-deep flood at Sahlgrenska hospital's emergency entrance (G22; G26).

\subsubsection{Lack of Systemic Valuation and Costing of Nature-Based Solutions}

Adapting existing developments by replacing pipes with open stormwater has proven effective for flood protection while also having other benefits, e.g., creating recreation areas [96]. Augustenborg, a low-cost housing area in Malmö, retrofitted in 1998, is often used as best practice. However, this was more than 20 years ago. Available financing is perceived as the great bottleneck for introducing adaptation measures, both at local and national levels (M2; M3; M5; M7; M8; M11; M15; G21; G22, G24). One interviewee perceives the need for systemic change: "We need to tear up many old ideas and cultures around this and realize that a myth about sustainability is that it is green and nice and realize they are quite tough issues [ ... ] This requires abandoning 'square economy' and 'square technology' methods and ways of working and instead to value what is important and to work with more functions in one solution" (G25).

A related issue is the lack of valuation of ecosystem services. One politician argued the lack of green space is because $70 \%$ of the land is private and outside municipality control (M3). Cost-benefit and life-cycle analysis tools are useful in comparing different options but are not used much, or at all, in the two cities. Some interviewees think they should be standard routine (G22). As they are not, ecosystem services provided by nature-based solutions (e.g., flood mitigation, recreation, and biodiversity) compared to solutions such as pipes are not systematically considered (M3). Instead, higher maintenance costs and space requirements are deterring factors (M5; M8; M11).

Another issue is the lack of cost sharing of construction and maintenance of nature-based solutions by all beneficiaries (G21; G22; M3). Each department has its own budget, making it cumbersome and risky for sectors and their responsible politicians to co-fund actions across departments. "Schools and sports venues have great potential to handle large amounts of rain, but the costs are put on those paying the rent for the particular building, which is another budget [ ... ] that is quite a large problem" (M4). Thus, there are strong incentives to save the budget for "core activities".

One result of the unclear priorities and lack of decisions at strategic, CP level is that much is left to the private developer of a DDP who "runs the show" (G19; G28; N30). Private real estate developers and investors are diverse, some more sustainability-oriented than others (M15). However, there are few economic incentives to implement nature-based solutions. Instead, the industry is driven by the profit motive, which leads to unsustainable choices (M9; M13; M15; G18; G19; G21; G25; G28; N30). 
Awareness and understanding of the benefits of nature-based solutions is not sufficient for change: "Everyone wants to take care of the water until they realize they have to build one house less; then there are not many who want to do it anymore" (M9). The cities use the "green area ratio" for each DDP (M5; M8) [103]. However, it is seen as a rather blunt instrument, only measuring green surface area and not specific conditions for ecosystem services [104]. It is also difficult (who pays?) to make interventions outside a specific DDP to mitigate flood risk, although it may be much more efficient (G16; G21). However, "compensatory measures" sometimes make it possible, in both cities, to include (e.g., green) elements elsewhere if they cannot be realized in the DDP area (M7; G21) [103].

Absent adequate economic incentives and a lack of trust in the private sector, planners in both cities see the need for more regulatory "muscle", including clarity on financing models, sanctions, and access to private land, to ensure nature-based solutions are integrated in the whole city and not only on public land (G20; G21; G22; M4; M9). However, some interviewees saw the adoption of more sustainable solutions as a matter of time and emphasized the importance of knowledge building and dialogue.

Introducing different budgeting and holistic valuation methods would, according to many interviewees, promote better decisions and create more sustainability (G21; G22; G23; M3; M6; M9; M11; N30).

\subsubsection{Densification "Mantra"}

Politicians' focus on densification (Section 4.2.1) was shown to influence error detection in several ways. Stress seemed to be a common factor in both cities:

- Stress discourages collaboration and innovation-Many interviewees mentioned that stress to produce housing discourages collaboration across different municipal departments, innovation, learning, and knowledge building (G16; G19; G21; G23; G24; M5; M6; M8; M9; N30). There is only time for already planned activities done in well-established ways. "Because you have too much to do, you don't have the energy to look outside of your own box" (G21). Some departments are perceived as more open to innovation, while others resist due to an already overwhelming workload (M9) [14].

- Hasty strategic planning-One interviewee did not think the Gothenburg CP revision process had allowed sufficient discussion on how to do "green densification". In a process lasting 1.5 years, working groups had informed the $\mathrm{CP}$, but the process was focused primarily on information sharing and had stopped prematurely (G23).

- Negative consequences not discussed-Malmö interviewees reported a reluctance among planners to highlight negative consequences of a DDP to politicians. Instead, they try to "sell" the DDP to achieve approval (M6; M9). Additionally, in both cities, there is information overload: politicians have a lot to read and decide in a short time, leaving little discussion for individual DDPs (G16; G19).

- Difficult to raise concerns-Interviewees in Gothenburg mentioned that, due to the densification paradigm, "softer" concerns for well-being were difficult to raise (G28). However, the CAB sometimes intervenes against the development of unsuitable areas, e.g., along the coast and water courses (M12).

\subsubsection{Other Knowledge-Building Barriers in the Organization}

Mainstreaming new knowledge and innovations in the city organization seemed to be challenged by various factors:

- Groupthink - One interviewee reflected on the approach to collaboration and learning, which assumed problems can be solved by sitting at the same table. While different perspectives are welcomed, consensus is the unspoken goal and preferred to deeper learning to prevent delays (G24). Another interviewee described the need for skill and experience to mainstream sustainability 
issues. In contrast, the setup of an Agenda 2030 secretariat in Malmö, run by younger people, was perceived to have isolated the issues (G23).

- Internal knowledge transfer-To create synergies, "green knowledge" and its role in adaptation needs to spread to city planners and other units that deal with similar issues. This requires "internal education" in both cities (M9; M12; G23). However, knowledge-building does happen, through highly appreciated events across departments with invited external experts (M5).

- Innovations linked to individuals-According to one interviewee, one of the main issues was that innovations were linked to individuals and not integrated into the city departments and at management level. If these individuals leave, knowledge-building must start afresh (G26).

- Knowledge transfer to city leadership is challenging-When issues are complex (such as water) and there are many steps between decision maker and expert, information may get distorted along the way (G22; M2; M9).

- Collaboration with academia is challenging-Research was perceived as too distant from real problems (G16; M10). "Sometimes we need concrete things, but research is not very concrete. If we ask researchers to help us look at something, they often reply: No, this is not research, it is implementation" (M10). Also, planners need to lead on the solutions: "There are many people who say how we need to work to make it better-and then it is good to get input on that. But then we have to sit and find the solutions ourselves, it has to come from us" (M10).

- Institutional memory-High staff turnover is a factor in both cities. New people do not know the history and there is no systematic way of learning from experiences (G24; M15). However, guidelines for DDP internal working processes are continuously adapted (M5). Additionally, key decision-support documents provide an important institutional memory of the last ten years (G18).

\subsection{Error Correction}

Decision making or error correction was found to be overly focused on densification without greening, i.e., grey densification (or error creation). At the same time, the policy landscape was seen as very complex, full of goal conflicts that had to be solved at local level.

\subsubsection{Densification "Mantra" to Address Housing Shortage}

All interviewees perceive that politicians push hard to correct the housing deficit-some describe it as a "mantra" (Section 4.1.3) or "housing shortage panic" [14]. "There is an enormous pressure from the politicians, and the city planning office is under pressure to produce housing and workplaces, and for them this is the main goal" (G23). One interviewee argued that the "panic" meant there was no time for rethinking densification, including "infill" development (G19) [105]. According to many interviewees, the densification mantra has resulted in a lower priority for sustainability issues at both national and city level (M8; G19; G21; G28; N30). For example, to reduce costs and speed up the building process, changes to legislation have prohibited some municipal demands on urban developers. Therefore, the ambition for a dialogue in Malmö between real estate owners and the municipality to stimulate sustainability had to be reduced considerably [106] (M8). However, interviewees from the private sector and right-wing politicians still think the DDP processes take too long and the cities have too much influence over the development process (G17; M1; M2).

\subsubsection{Generic $\mathrm{CP}$ and Many Overlapping Policies Leading to Goal Conflicts}

Many respondents considered the $\mathrm{CP}$ should play a more important role to support the handling of goal conflicts at DDP level. Without sufficient strategic support and given limited capacity (time), systemic thinking and acting was seen to get lost in more daily "firefighting" (M4; M9; G19; G21; G24; G25; G28; N30). Two interviewees from both cities also pointed out the CP had become less concrete over time, with more text and fewer maps (M8; G19). One interviewee saw the fuzzy texts as creating the false impression that issues will be addressed and solved (M6). More strategic 
clarity could improve implementability and make collaborative planning less cumbersome and time consuming [107]. For example, requirements for developing housing at a certain level could be set for areas already at risk of floods, including private land (M6; M9). However, some interviewees believed the $\mathrm{CP}$ is fit for purpose, and the problem is rather that in the implementation phase, planning documents are not followed (M2; M3; Section 4.3).

The fuzziness is further increased by an overwhelming number of national and local plans that are sometimes contradictory, without any priority between them (M2; M6; M10; M12; M14; M15; G25; G28). This issue was mainly stressed by Malmö interviewees: "I think it is a problem that the green plan says: 'Malmö should be the most green city', the Development plan says 'Malmö should be the most dense city', and the extreme rainfall plan says 'Malmö should be best at that', but you never weigh them against each other" (M10). Politicians highlighted that one reason to keep strategic documents generic, vague, and ambiguous is to avoid handling difficult economic or political consequences (M3; M2). Vagueness and ambiguity can have many advantages within organizations, e.g., increased flexibility and creativity [108]. However, they can also be used as a way to avoid liability. Interviewees in both cities considered the lack of priorities and coordination as slowing down the urban development process (M15, G21, G24). However, eventually priorities are set by politicians. In Malmö, one politician perceived social issues as always to be prioritized before environmental (M3).

\subsubsection{Lack of Legislation}

Two of the issues identified in error detection are linked with a deficit in national legislation. First, water planning is not regulated to occur at river-basin level (see Section 4.1.1), and there is no legislation facilitating water management across municipalities and DDPs (M9; G16; G22). However, the Stockholm and Gothenburg CABs are exceptions (M6; M7). Changing water flows for the common good is in general difficult, as legislation is focused on private rights. An old system of joint property societies gives exclusive rights to all landowners linked to the water body. For these, the amount of water flow is set by court rulings. Changing them requires unanimous agreement of all involved, but many joint property societies are no longer active, their members unknown (M12; G20; G28; N29; N30). Interviewees from the transport administration mentioned planners often want to use road drainage for the DDPs, as they are properly managed. They have sometimes allowed it, but cannot admit to it on paper, as they would then be responsible for maintaining quality (G28; N29; N30).

Secondly, many interviewees mention there is a lack of municipal control on existing development on private land to limit risks (M4; M10; M12; G16; G21, see Section 4.1.2). The Planning and Building Act has been amended in accordance with the climate adaptation strategy [109], but this only regulates new developments. For existing developments, individual land/house owners are responsible, but their willingness to carry out measures varies (M4; M10). Consequently, all measures are taken on public land so that government has long-term control over them (G20; G26). The lack of coherent control is summarized by one interviewee: "Responsibility sits with individual actors, but the solutions are needed at the large scale" (M12). In general, legislation changes often target this Act, but there is need for coordination with, and updating of, many other Acts, e.g., the Environmental Code (M9; M10; G18; G20).

\subsection{Receptiveness to Error Detection}

Many interviewees from both cities testify that siloed organization and lack of leadership at national and local levels contribute to system fragmentation (M4; M15; G5; G18; G20; G25; G26).

\subsubsection{Siloed Organizations at City Level}

One major issue identified by many interviewees is the siloed organization in the cities, as seen in Figure 5 (M2; M3; M5; M9; M15; G20; G25; G26; G16). Different departments and thematic committees work independently and address different interests. They apply their own rules, strategies, and guidelines 
and have their own routines and ways of working. In Gothenburg, silos are also exacerbated by long physical distances between departments (G21).

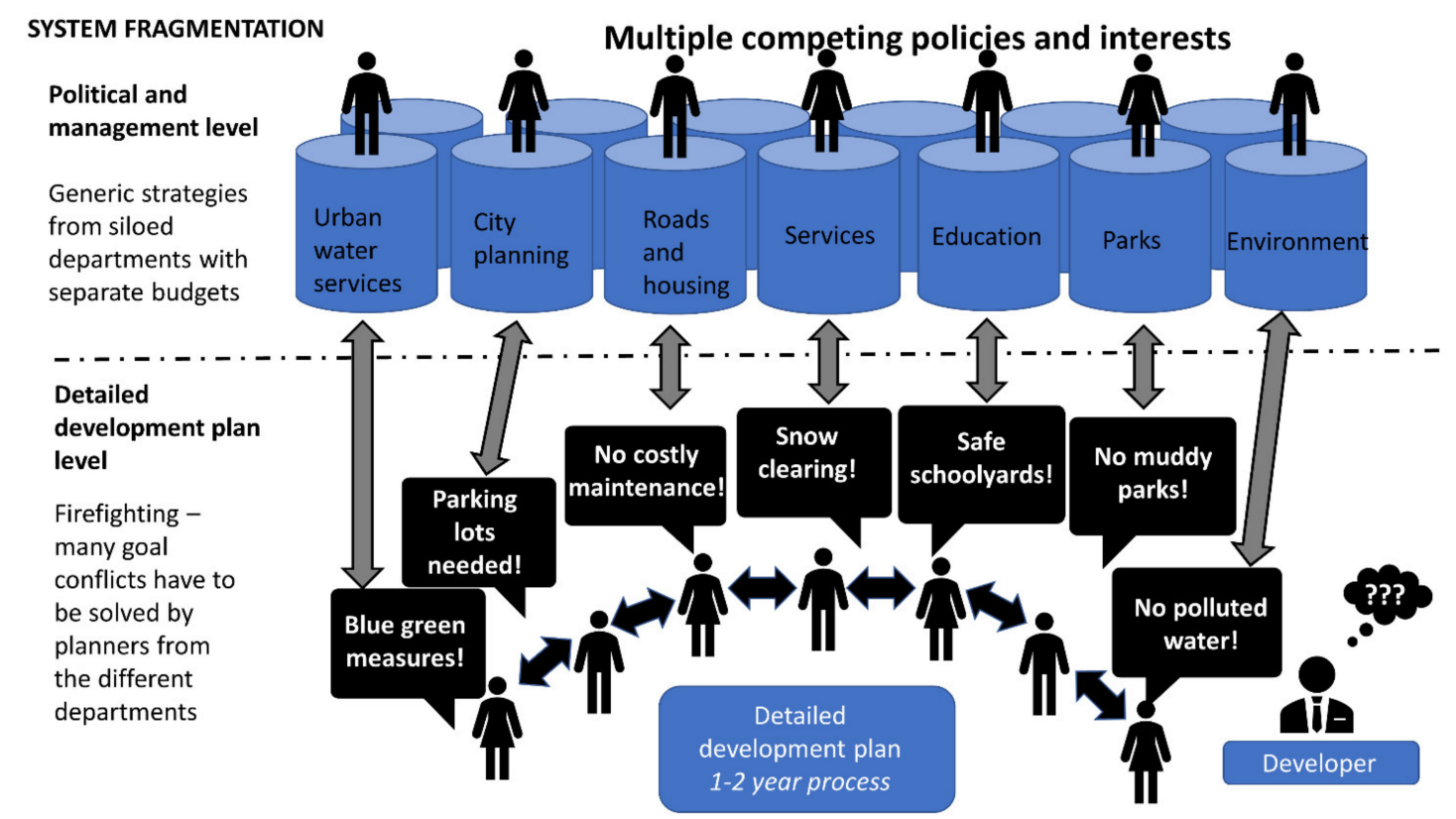

Figure 5. Siloed management creates issues for detailed development planning and implementation, where a lot of goal conflicts must be solved. Different departments have their own unique perspectives and priorities, working according to a multitude of overlapping policies. For a developer, for example, the city seems to consist of many actors.

The silo division results in several barriers to collaboration and learning:

- Competing departments have an "us and them" attitude, instead of coordination and multifunctionality or working as a team for the common good of the city. For example, in DDP planning, many people come together from different departments, but it is difficult to make decisions, as they all defend their interests (G18; M3; M15).

- The decision making in these multi-departmental groups can also be slow and difficult, given the need to go back and get line approval, which may even stall processes (G24). This democratic process of multiple actors ruled by silos and their respective policy documents (see Section 4.2.2), is so diffuse that an interviewee has called it a "cloud" (M9; M15).

- Lack of communication, understanding, and trust-Silos make it difficult to coordinate the steps in the DPP process between the departments (M5). Clear communication of departments' requirements was perceived as helpful but challenging due to time constraints, lack of understanding, trust, and personalities (M5).

- Myths and fears-Adopting innovations seems to be difficult as there are many myths and fears surrounding them (M3; M5; M9). For example, many people interpret nature-based solutions as wetter (and muddier) environments (M4; M6; G19).

Several interviewees saw the siloed organization as the historical legacy of dominant leaders who for many years shaped the cities' urban development (G19; G24; M3). Now, new people have come in with a more collaborative leadership style, but the city organization has not yet developed an integrated, systemic view, which also contributes to a fragmented approach (M3; M15; G25). "We are far from thinking sustainably and transition to a sustainable society. Now, we are working with a fragmented approach. We need a much bigger holistic picture" (G25). However, other interviewees consider "Gothenburg to have forward and a holistic thinking" (G22). 
Cross-departmental planning is underway in the two cities including strategic planning at higher levels, bringing in all issues and synchronizing input from different actors in a timely way. For example, in Gothenburg, the city council has assigned the city executive office to investigate how they can improve collaboration and develop new routines for climate adaptation. So far, only the regulations for the different departments have been adjusted. For example, the Department of Sustainable Waste and Water has been delegated a coordinating responsibility for water across the silos, which was perceived as providing important support for integrated solutions (G21).

In Malmö, a cross-sectoral working group for extreme rainfall was established, which concluded there was a need to hire a water planner. One interviewee, however, considered that such groups would not be needed if management were more supportive of collaboration, coordination, and holistic thinking across silos (M3). Another interviewee suggested solving the silo problem by allocating flooding and adaptation as a prioritized task to one of the political thematic committees instead of spreading it over multiple sectors. This would result in quicker decisions and clearer priorities (G20).

\subsubsection{Missing Leadership and Organization at Multiple Levels}

Interviewees from both cities see a need for more national engagement and less fragmented organization at multiple levels (M4; M13; M14; G16; G20; G28; N30). There are many national departments and agencies involved, posing barriers to coordination, learning, and action (G21; G20). More national engagement, combined with a systemic view, would have speeded up many of the needed adaptations: "Support from the national level has been missing, for example in terms of financing models and models for responsibilities, and the state is very passive. Only now have they started to act, but too little" (G20). The CABs have the mandate to coordinate but no real authority, due to the municipal planning monopoly (M14; G27). This results in inaction. In addition, the dual role of the CABs—regulation/surveillance and support—is seen as problematic (M13; M14; G20). Some interviewees from Gothenburg highlight the need for cost-sharing between local and national levels, such as for large-scale infrastructure, e.g., the planned storm barrier in Gothenburg (G4; G16).

\subsection{Responsiveness to Error Correction}

The results illustrate that implementation does not follow from strategic planning. Although both cities have ambitious targets on nature-based solutions stated in their respective CPs, many interviewees report this is not reflected in actual land use (M3; M4; M5; M6; M8; M12; M15; G16; G21; G22; G24; G28). "We said in the last CP from 2014 that we will build a city that should be denser but also greener, but to be honest we have not seen the effects of that" (M4). This is perceived to be caused by a lack of understanding of implementation (Section 4.4.1), the difficulty of changing existing working cultures (Section 4.4.2), and a lack of knowledge (Section 4.4.3). This limits the space for innovation (see Figure 6).

\subsubsection{Strategies and Plans Lacking in Understanding of Implementation Realities}

One issue raised by some interviewees was the lack of understanding by strategists and planners of the realities of implementation (G16; G24; G25; M5; M9), e.g., costs (G25). When implementation needs to solve all practical problems, priorities needs to be made and some planned measures are cancelled without discussion (G16). Thus, three interviewees saw a need to talk about economy and implementability earlier in the urban development process (G16; G24; G25). For example, Frihamnen, the former harbor area in Gothenburg, was prized for its development plan, but this was abandoned after a year as it was too costly. A researcher expressed surprise: "How was this possible? Why did they not calculate the costs earlier, and look at the physical conditions, which was a reason the plan was too expensive?" (G24). 


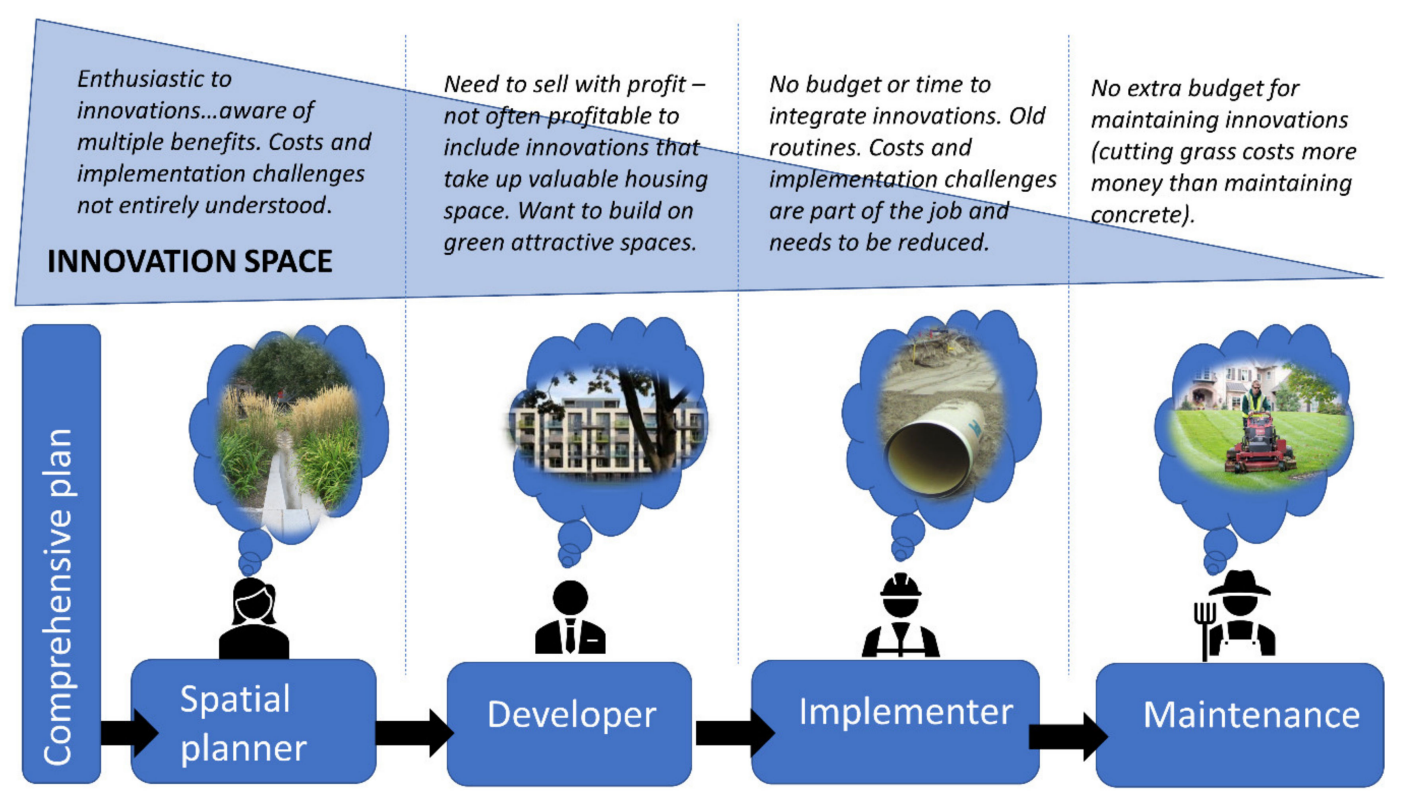

Figure 6. The generic fragmented process and reduction of innovation space in detailed development planning due to different drivers.

\subsubsection{Difficulty of Changing Routines and Working Culture}

Another reason given for shifting the course of implementation is the difficulty of changing existing routines or working cultures, both at the city and city department levels. Interviewees considered that actions were not supported by investigations or tools, but based on routines, assumptions, and sometimes fears and mistrust (G16; G21; G22). "We have always done it this way, and they don't get it anyway" (G16). "This demands a lot in terms of learning across the borders and collaboration and cross-sectoral work" (G23). In other cases, the difficulties are related to how the whole organization is structured. Some interviewees mentioned an "implementation deficit"; solutions are available, but people do not have the specific tools or mandates how to implement them (G21; G23; M9). This relates, for example, to the need for a different financing model for nature-based solutions (Section 4.1.2). One planner said that when the roads and housing departments work out the details, they prefer low maintenance costs and often favor concrete over nature (G5; M8). The thematic plans in Gothenburg were considered to influence the working culture positively by putting demands on developers and making it easier to fund nature-based solutions within different departments (G26).

\subsubsection{Need to Develop City Actors' Knowledge}

To introduce and implement adaptations, the knowledge of different actors (real estate owners, politicians, planners) needs to increase (see also Section 4.1.4). Many interviewees considered real estate owners the most important, as already developed urban spaces cause the biggest risks. Therefore, they need to be involved and understand the value of managing water and creating green spaces in a larger context (M10; G18) [14]. They need to become more aware of how to build houses in a different way to cope with increasing heat waves, etc. (G18). However, engaging in dialogues for knowledge development was experienced as a slow process, and real estate owners are not aware of their responsibilities and what needs to be done, often ignoring the issue.

\section{Discussion}

In this section, we will discuss the results of the two case studies and their implications for social learning theory and for systemic and transformative learning and management strategies. We will end with the limitations of the research and recommendations for further research. 
We found multiple social learning barriers for realizing the green and adaptive goals in the comprehensive plan (see Figure 6 and Appendix C). First, there are several barriers related to error detection or risk perception, which make a collective (social) learning more difficult. For example, the lack of systemic valuation and costing of nature-based solutions means a lack of risk perception about these values. This is a common phenomenon and has often led to a situation where the values of nature are not realized and recreated in urban spaces until they start to be scarce [34]. Such awareness can be slow to develop as shown by acid rain, climate change, droughts, desertification, and famines, for example [110]. Risk perception is determined by socio-cultural standards and cognitive bias, e.g., preferences and norms, in contrast to physical standards, which makes it also susceptible to political agendas and discourses in society, such as the densification paradigm [111]. In the same way, norms are well known for inhibiting double-loop learning [51]. For example, the pressure to deliver on high volumes of housing (adhering to norms) was shown to reduce space for collaboration through groupthink, which inhibits critical voices and knowledge building on green and adaptive solutions.

To address the perceived risks with error correction, the results illustrate that many different areas would need to be simultaneously addressed to adapt the system to support greening the city. It is known that various processes of social learning are needed to build risk awareness with decision makers and the public [42]. However, the results illustrate the large step between risk perception and decision making on (adequate) solutions. For example, many interviewees, both planners and politicians, identified financial mechanisms as a barrier; however, such decisions would need to become accepted by a broad segment of decision makers at executive level. The challenge is then to transmit the risk perception in an effective way and build the evidence so that it is well received [112]. However, it has been shown that even if decision makers have gained knowledge about the severity and causes of problems and the benefits and risks associated with various policy alternatives, individual ideology or interests and the exercise of power often override this [113]. We refer to this difficulty of connecting error detecting and correction below (see Section 5.1) as opacity.

In addition, we found that siloed organizations and fragmented and weak national support make error correction/decision making less receptive to error information. It was perceived to be difficult to create understanding with other departments that had their own interests in focus and not necessarily the interest of the whole city. Here, the appointment of the Department of Sustainable Waste and Water (Gothenburg) to coordinate responsibility for water across the silos and a cross departmental working group (Malmö) is a very important intervention and makes the system more receptive to learning and risk perception.

The results also illustrate how correcting or adapting the more strategic aspects of the system may not be sufficient as there may be resistance to error correction in implementation. For example, working cultures that prefer already established actions within the familiar frames (i.e., single-loop learning providing a barrier). Various conditions for implementation also play a role here, for example financial incentives and budgeting; which calls for consideration of these factors earlier in the planning process. This requires increased collaboration between different actors and in this process learning from but also building knowledge and awareness with planners, implementers, real estate developers, and owners.

Addressing these social learning barriers is critical to adhere to the comprehensive plan, as it ought to be a document with credibility and legitimacy. Unfortunately, discrepancy between plans and real land use is not an unusual phenomenon (e.g., [114,115]). Here, the insights from this study could contribute to recognizing and remedying the barriers to learning and change.

The results illustrate an "adaptation inertia" in the system, where social learning barriers, influenced by both governance elements such as legislation, forms of collaboration (e.g., bridging silos), and socio-cognitive elements (norms, paradigms) play an important role. The dynamics of adapting a governance system has been described in the policy learning literature. Incremental changes in policy, ideas and discourses is known to occur [116]; however, most theories point out that the social learning is sped up at certain moments in time. Some use the metaphor of "punctuated equilibrium", 
where long periods of incremental change are punctuated by brief periods of major policy change where paradigms can change rapidly [117]. Other theories refer to moments when rapid changes occur as "windows of opportunity" [112]. The irregular pattern of policy change is attributed to the same factors determining path dependency, where different frictions slow down the policy process [118]. However, over time, "pressure" builds and accumulates within the policy subsystem until a large and dramatic policy change results of conflict or extraordinary effort [119]. The barriers to social learning identified here can contribute to the understanding of these dynamics.

\subsection{Three Types of Flaws}

The results show how the social learning infrastructure in Gothenburg and Malmö is flawed in three different ways (see Appendix D, Figure 7).

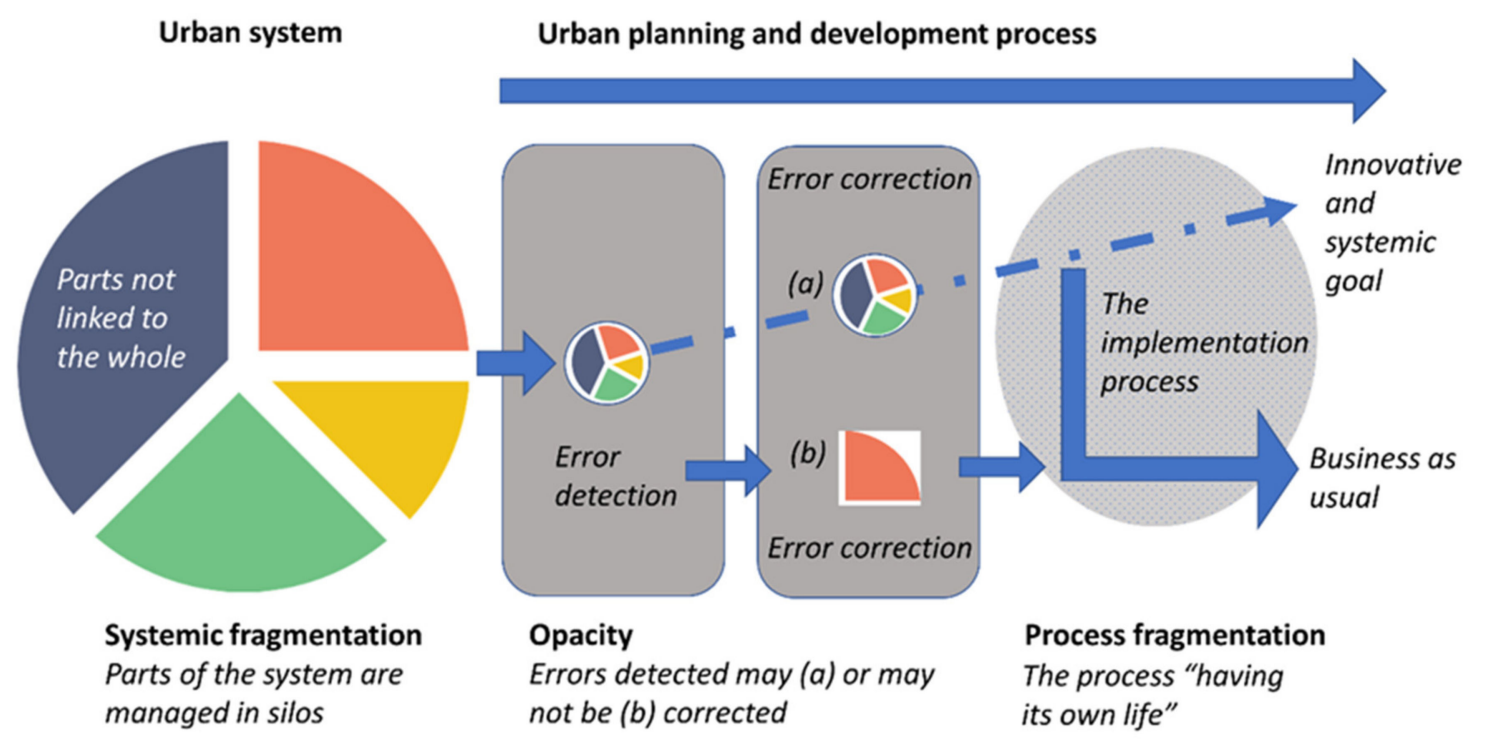

Figure 7. Flaws in systemic approach, opacity, and process.

First, there are systemic flaws, where parts of the system are not connected to the whole. For example, (small-scale) DDPs are only recently being connected to more holistic river-basin planning (Section 4.1.1). Additionally, there is a lack of holistic valuation of ecosystem services (Section 4.1.2). Receptiveness to error detection is reduced by siloed organizations that most often detect errors relating to their sectoral interest (Section 4.3.1). The many policy documents produced by each silo overlap, resulting in many goal conflicts. In the more detailed planning phase (see below under process), this results in "firefighting" and a loss of the systemic thinking present in the CP (Section 4.2.2).

Secondly, there is a lot of opacity. There are many institutional barriers to error detection and correction and between error detection and correction. Even if all the tools to achieve a systemic approach in error detection are available (e.g., all ecosystem services could be included in a cost-benefit analysis), this information is not required because different actors, often with different perspectives, power, and interests, are involved in error correction. Additionally, it is hard to communicate errors if this challenges dominant paradigms, e.g., the densification mantra (Section 4.1.3) [51,120].

Thirdly, there are process-related flaws. The lack of a systemic approach results in strategies and planning, and even decisions, being disconnected from implementation. Business as usual, combined with the need for sectoral effectiveness, creates little space for innovation, which results in implementation "having its own life" (Section 4.4). In both cities, a lack of financial incentives, time, and knowledge were seen to reduce the receptiveness and willingness to adopt innovations. There was a resistance to learning new ways of seeing and doing things and, not the least, to "unlearning" old ways, implicit assumptions, and norms. This is related to the tension between existing certainty of established routines and practices vs. the uncertain outcomes and rewards of 
innovation [68,121,122]. Additionally, strategic actors (including planners) in the two cities sometimes did not seem to understand the constraints, including financial, of the actors in the implementation process, partly because of lack of interaction. This calls for knowledge co-production involving planners and implementers, and possibly for academia to support collective understanding and actions. Such strategies could promote unlearning by facilitating strategic deliberations, building trust $[64,123]$, and developing a broader understanding shared by multiple actors.

These insights contribute to the empirical knowledge about which barriers there are for implementing planning. This knowledge is often missing, because even though planning processes are supposed to be evaluated, this rarely happens [40].

\subsection{Learning Flaws Lead to Undesirable Outcomes}

In both cities, these flaws lead to a discrepancy between the goals set out in strategic planning documents and actual land use. Specifically, this relates to sustainability goals of including adequate risk-reducing nature-based solutions (e.g., Section 4.4). Strong underlying factors are the political goals of densification and strong economic and social drivers, on the one hand, and a lower priority to environmental sustainability, climate adaptation, and risk reduction, on the other. The result is increased risk, contrary to the $\mathrm{CP}$ communicated with citizens. Citizen involvement could potentially help question and provide a counterweight to the implicit assumptions of densification, assuming citizens want sustainable and resilient cities. This could improve transparency and bring actual land use in line with sustainability goals.

\subsection{Imperative for a More Systemic Management Paradigm}

We found useful the systemic approach to social learning in terms of error detection and correction applied here for identifying issues and remedies for good urban water governance. Therefore, we expect it also to be useful in other forms of environmental governance. It can be used to identify multiple intervention points, approaching urban water governance as a complex web of interlinked issues and remedies. This can be contrasted with an approach that looks at remedies as isolated interventions in individual silos.

We have summarized a strategy for systemic learning for urban water governance in Appendix E and Figure A1. The realization that systemic approaches are desirable is not new [1,2]. Systemic analysis has long been promoted by academic literature and has also been applied to policy $[124,125]$. However, this approach has not gained much ground in practice, apart from some success of "soft systems approaches" [126] and network analysis [127]. One part of the explanation may be the complexity of systems analysis. Instead, for over 30 years, more disaggregated approaches, e.g., "new public management", have been preferred. One of the key recommendations of new public management has been to deliberately disaggregate large, multifunctional public bodies and replace them with a series of single-purpose bodies delivering specific services. Although arguably more operative and efficient in the short term, this approach has been criticized for limiting innovation, as it focuses on efficient use of resources in a single sector only [122,128]. There is a surprising lack of evaluation of the new public management approach [128]. However, related studies show larger structural reforms have little impact on overall performance, which would have been expected if the new public management approach had been more efficient overall [129]. The evidence given here shows that social learning theory could contribute to more systemic public management.

\subsection{Limitations of the Research and Recommendations for Further Research}

The number and type of interviewees in this study is only a smaller representation of the views and perspectives present in the two cities. However, having identified common issues that many interviewees in both cities have mentioned, and finding support from literature, we consider the results to be verified. Semi-structured interviewing also means that different topics are brought up in each 
interview that cannot be covered by all interviews, making some statements seem less supported than they may really be.

While the recommendations may be only partly relevant for other cases, we think the generalizability of this study makes more general conclusions possible. However, this study would benefit further comparison with other cities aiming to achieve multiple goals of densification, sustainable development, resilience-building, and climate adaptation.

This paper has raised questions about the role of systemic approaches on urban development. We conclude that future research on this needs to be well-grounded in practice, through action research and co-production of knowledge, to look for answers about why systems approaches are very much promoted in theory, but not well implemented in actual systems. Perhaps there are great challenges in operationalizing and implementing systems approaches, including understanding non-linear feedbacks, deeper systems structures, and long-term processes [130]. However, the alternative is not sustainable, nor resilient. Finding ways for more systemic management approaches could contribute to society through different forms of organizational planning and valuation approaches, developing a new systemic public management.

Supplementary Materials: The following are available online at http://www.mdpi.com/2071-1050/12/17/6916/s1: interview questions and additional quotes from the interviewees to further illustrate the findings.

Author Contributions: Conceptualization: ̊̊.J. and E.M.; methodology: ̊̊.J.; validation: ̊̊.J; formal analysis: Å.J; investigation: Å.J; writing—original draft preparation: Å.J.; writing—review and editing: ̊̊.J. and E.M.; visualization: Å.J.; project administration: Å.J.; funding acquisition: Å.J. All authors have read and agreed to the published version of the manuscript.

Funding: This study was financed by the Swedish Research Council VR (international postdoc grant number 2017-06214).

Conflicts of Interest: The authors declare no conflict of interest. The funders had no role in the design of the study; in the collection, analyses, or interpretation of data; in the writing of the manuscript; or in the decision to publish the results.

\section{Appendix A}

Table A1. Interview guide.

\begin{tabular}{|c|c|c|}
\hline & Theme & Questions \\
\hline 1. & $\begin{array}{l}\text { Fulfilling goals: climate adaptation }+ \\
\text { sustainable development }+ \\
\text { densification }=\text { impossible equation? }\end{array}$ & $\begin{array}{l}\text { - I have read in the Comprehensive plan }(\mathrm{CP}) \text { about the goals of densification } \\
\text { and at the same time a sustainable/green city and adaptive capacity taking } \\
\text { care of extreme waters. Is it possible to reach all these goals? } \\
\text { Are there prioritizations that are needed, which means that one of the goals } \\
\text { will not be fulfilled? }\end{array}$ \\
\hline 2. & $\begin{array}{l}\text { How to ensure green areas for } \\
\text { climate adaptation?/How do you } \\
\text { build resilient and sustainable? }\end{array}$ & $\begin{array}{l}\text { - What is needed to build a city that is robust and adapted to climate change? } \\
\text { - Is there clarity on how this should be done? } \\
\text { - } \quad \text { Are the good examples replicated? Why, why not? }\end{array}$ \\
\hline 3. & $\begin{array}{l}\text { Efficiency and fora for good } \\
\text { collaboration in the administration? } \\
\text { (In implementation, decision- } \\
\text { and working-processes) }\end{array}$ & $\begin{array}{l}\text { - Can you describe the processes and forms for the collaboration/cooperation? } \\
\text { - Do you think that implementation strategies, working and decision } \\
\text { processes are working well in the administration so that you can reach the } \\
\text { goals in practice? } \\
\text { - What do you think of the efficiency and forms of collaboration and } \\
\text { communication (e.g., in different thematic committees?) } \\
\text { Would there be room for improvement in the forms for collaboration } \\
\text { and communication? } \\
\text { Have you got suggestions for constructive solutions to improve } \\
\text { implementation strategies, decision and working processes? }\end{array}$ \\
\hline 4. & Where does learning happen? & $\begin{array}{l}\text { - How and where does learning happen in the described } \\
\text { collaborative process? } \\
\text { - Who is learning? } \\
\text { - What factors influence learning according to your experience, e.g., what } \\
\text { environments/situations stimulate learning? }\end{array}$ \\
\hline
\end{tabular}


Table A1. Cont.

\begin{tabular}{|c|c|c|}
\hline & Theme & Questions \\
\hline 5. & $\begin{array}{l}\text { Are there barriers to learning? } \\
\text { Norms and rules in communication } \\
\text { and behavior The barriers are not } \\
\text { easily identified as it may be a } \\
\text { behavior of which people are } \\
\text { not aware. }\end{array}$ & $\begin{array}{l}\text { - What provide barriers/inhibitions to learning? } \\
\text { - Do you think that the information that is provided (to civil society, planners, } \\
\text { and politicians etc.) is correct, free, and gives alternatives, create own } \\
\text { responsibility and role? Or are there behaviors that try to control what } \\
\text { information is communicated, (to win, suppress negative information?) Is } \\
\text { there a difference between how people think they act and how they } \\
\text { really act? } \\
\text { Is it possible to discuss suggestions openly? Are there implicit norms that } \\
\text { lead to a lack of questioning (e.g., co-workers do not criticize goals and } \\
\text { visions that management is driving)? (Is the result hiding of information?). } \\
\text { - Who needs to build knowledge? Politicians, planners, citizens? } \\
\text { - How should it be done? }\end{array}$ \\
\hline 6. & $\begin{array}{l}\text { Multi-level governance: Links } \\
\text { between national level (state } \\
\text { authorities, county administration } \\
\text { boards) to the municipality that has } \\
\text { a planning monopoly }\end{array}$ & $\begin{array}{l}\text { - How do you think the national level can support the city best? } \\
\text { Is more/less governance needed, support, coordination, and regulations } \\
\text { from national level? }\end{array}$ \\
\hline 7. & $\begin{array}{l}\text { Cross-sectoral } \\
\text { management-integration-holistic } \\
\text { view on water }\end{array}$ & $\begin{array}{l}\text { - How does the cross-sectoral planning work-is a holistic view of the } \\
\text { resource possible? } \\
\text { Is there integration between city planning, climate adaptation, water quality, } \\
\text { and flooding? }\end{array}$ \\
\hline 8. & Power: planning vs. politics & $\begin{array}{l}\text { - Where do you think the decision making takes place? By the planners or by } \\
\text { the politicians? } \\
\text { - Is there transparency about the different alternative solutions, how they } \\
\text { have been developed, and can be evaluated? } \\
\text { Does the political ideology play a role in the decision-making process e.g., } \\
\text { are there any principal political decisions taken that still play a role such as } \\
\text { public land ownership, private enterprising etc.? }\end{array}$ \\
\hline
\end{tabular}

\section{Appendix B}

Table A2. List of interviewees, Malmö.

\begin{tabular}{lll}
\hline \multicolumn{1}{c}{ No } & \multicolumn{1}{c}{ Category } & \multicolumn{1}{c}{ Function } \\
\hline M1 & Politician (right wing) & Conservative party (M) \\
M2 & Politician (right wing) & Conservative party (M) \\
M3 & Politician (left wing) & Green party (Mp) \\
M4 & Strategic planner & City Planning Office \\
M5 & Planner & City Planning Office \\
M6 & Planner & Roads and Housing Department \\
M7 & Planner & Roads and Housing Department \\
M8 & Planner & Environmental Office \\
M9 & Project coordinator & Environmental Office \\
M10 & Manager & Water utility \\
M11 & Project coordinator & Social Housing Authority * \\
M12 & Regional planner & County Administration Board, Scania \\
M13 & Regional planner & Scania Region \\
M14 & Regional planner & Scania Region \\
M15 & Private sector & Real estate company \\
\hline
\end{tabular}

Table A3. List of interviewees, Gothenburg.

\begin{tabular}{lll}
\hline \multicolumn{1}{c}{ No } & \multicolumn{1}{c}{ Category } & \multicolumn{1}{c}{ Function } \\
\hline G16 & Politician & Green party (Mp) \\
G17 & Politician & Conservative party (M) \\
G18 & Strategic planner & City Executive Office \\
G19 & Planner & Real Estate Office \\
G20 & Planner & City Planning Office \\
G21 & Strategic planner & Dept of Sustainable Waste and Water (utility) \\
\hline
\end{tabular}


Table A3. Cont.

\begin{tabular}{lll}
\hline \multicolumn{1}{c}{ No } & \multicolumn{1}{c}{ Category } & \multicolumn{1}{c}{ Function } \\
\hline G22 & Expert & Dept of Sustainable Waste and Water (utility) \\
G23 & Senior manager & Environmental Office \\
G24 & Researcher & University of Gothenburg \\
G25 & Senior manager & Municipal development company \\
G26 & Private consultant & Company involved in water planning \\
G27 & Regional planner & County Administration Västra Götaland \\
G28 & Regional planner & Swedish Transport Administration \\
\hline
\end{tabular}

Table A4. List of interviewees, National level.

\begin{tabular}{lll}
\hline \multicolumn{1}{c}{ No } & \multicolumn{1}{c}{ Category } & \multicolumn{1}{c}{ Function } \\
\hline N29 & Senior manager & Swedish Transport Administration \\
N30 & Planner & Swedish Transport Administration \\
\hline
\end{tabular}

\section{Appendix C}

Analysis of Barriers to Error Detection, Correction, Receptiveness to Error Detection, and Responsiveness to Error Correction

The analysis also considers context (triple-loop learning) assumptions (double lop learning) and Action (see Figure 2) (++ is not a barrier).

Table A5. Error detection.

\begin{tabular}{|c|c|c|c|}
\hline & Context & Assumptions & Action \\
\hline Planning & $\begin{array}{c}++ \text { Water-based planning at river } \\
\text { basin level detects risks for } \\
\text { development (structural plans, } \\
\text { action plans) }\end{array}$ & $\begin{array}{l}\text { Water management at river basin level } \\
\text { should be a structural element in } \\
\text { spatial planning }\end{array}$ & $\begin{array}{l}\text { Plans exist, but whether plans } \\
\text { are going to be financed and } \\
\text { implemented is unclear (e.g., } \\
\text { lack of financial mechanisms) }\end{array}$ \\
\hline Financing & $\begin{array}{l}\text { Financial mechanisms (budgets) } \\
\text { do not detect that green } \\
\text { solutions have societal values } \\
\text { beyond short term profits }\end{array}$ & $\begin{array}{l}\text { Needs for alternative budgeting and } \\
\text { holistic valuation methods (fundamentally } \\
\text { different from current system in use) }\end{array}$ & $\begin{array}{l}\text { Short term financial incentives } \\
\text { make implementers take other } \\
\text { choices than in plans ("process } \\
\text { has its own life") }\end{array}$ \\
\hline $\begin{array}{l}\text { Densification } \\
\text { paradigm }\end{array}$ & $\begin{array}{l}++ \text { Green paradigm (visions of } \\
\text { green written into the CP) but } \\
\text { implicitly, more prioritized } \\
\text { paradigms are (grey) } \\
\text { densification and } \\
\text { social sustainability }\end{array}$ & $\begin{array}{c}\text { Stress discourages collaboration } \\
\text { and innovation } \\
\text { Hasty strategic planning } \\
\text { Difficult to raise concerns } \\
\text { Negative consequences not discussed } \\
\text { Information overload }\end{array}$ & $\begin{array}{l}\text { Lack of realisation of } \\
\text { green visions }\end{array}$ \\
\hline
\end{tabular}

Table A6. Error correction.

\begin{tabular}{|c|c|c|c|}
\hline & Context & Assumptions & Action \\
\hline $\begin{array}{l}\text { Paradigm } \\
\text { (densification } \\
\text { mantra) }\end{array}$ & $\begin{array}{c}++ \text { Green paradigm (visions of } \\
\text { green written into the } C P \text { ) } \\
\text { Environmental sustainability } \\
\text { mechanisms reduced }\end{array}$ & $\begin{array}{c}\text { Politicians push hard to correct housing } \\
\text { deficit (not acknowledging values of green) } \\
\text { To increase housing development, } \\
\text { (sustainability) demands on developers } \\
\text { is reduced }\end{array}$ & $\begin{array}{l}\text { The green paradigm is not } \\
\text { implemented due to various } \\
\text { barriers (e.g., political priorities } \\
\text { for housing development) }\end{array}$ \\
\hline $\begin{array}{l}\text { Planning and } \\
\text { strategy }\end{array}$ & $\begin{array}{l}\text { Generic } C P \text {-nice words but } \\
\text { little concrete guidance } \\
\text { Many overlapping policies, } \\
\text { leading to goal conflicts at } \\
\text { DDP level }\end{array}$ & $\begin{array}{l}\text { CP giving a false impressions issues will be } \\
\text { solved, need to challenge assumptions that } \\
\text { all is being resolved } \\
\text { Need for strategic coordination. Integration } \\
\text { of diverse values for societal benefit }\end{array}$ & $\begin{array}{l}\text { Generic CP is not the problem, } \\
\text { but that planning documents are } \\
\text { not followed } \\
\text { Lack of priorities and } \\
\text { coordination slows down } \\
\text { implementation }\end{array}$ \\
\hline
\end{tabular}


Table A6. Cont.

\begin{tabular}{|c|c|c|c|}
\hline & Context & Assumptions & Action \\
\hline Legislation & $\begin{array}{l}\text { River basin management } \\
\text { not mandatory } \\
\text { Management across several } \\
\text { municipalities has } \\
\text { legal challenges } \\
\text { Water is private property } \\
\text { Measures on private land is } \\
\text { outside municipal control } \\
\text { Coordination needed across } \\
\text { several laws }\end{array}$ & $\begin{array}{l}\text { Legislation is not supportive of integrated } \\
\text { and coordinated actions }\end{array}$ & $\begin{array}{c}\text { Barriers to action } \\
\text { Lack of incentives to action } \\
\text { Lack of integrated actions }\end{array}$ \\
\hline
\end{tabular}

Table A7. Receptiveness to error detection.

\begin{tabular}{|c|c|c|c|}
\hline & Context & Assumptions & Action \\
\hline Organisation & Siloed organisations at city level & $\begin{array}{c}\text { Silos defend their interests "us and } \\
\text { them attitude" } \\
\text { Need to get line approval } \\
\text { Diffuse process-“a cloud" } \\
\text { Lack of communication, understanding, } \\
\text { and trust } \\
\text { Time constraints } \\
\text { Myths and fears surrounding } \\
\text { green solutions }\end{array}$ & $\begin{array}{c}\text { Slow decision making } \\
\text { Stalled processes } \\
\text { Difficult to coordinate the steps } \\
\text { in the DPP process between } \\
\text { the departments }\end{array}$ \\
\hline ++Organisation & $\begin{array}{l}\text { ++Department of Sustainable } \\
\text { Waste and Water (Gothenburg) } \\
\text { has been delegated a } \\
\text { coordinating responsibility for } \\
\text { water across the silos } \\
\text { ++In Malmö a cross } \\
\text { departmental working group } \\
\text { coordinate actions }\end{array}$ & $\begin{array}{l}\text { Providing important support for } \\
\text { integrated solutions } \\
\text { Supporting collaboration }\end{array}$ & $\begin{array}{c}\text { Encouraging more adaptive and } \\
\text { sustainable actions }\end{array}$ \\
\hline
\end{tabular}

Table A8. Responsiveness to error correction.

\begin{tabular}{|c|c|c|c|}
\hline & Context & Assumptions & Action \\
\hline Planning & $\begin{array}{l}\text { Lack of conditions for } \\
\text { implementing plans (financial, } \\
\text { organizational, etc.) }\end{array}$ & $\begin{array}{l}\text { Need to talk about implementability and } \\
\text { financing earlier in the process }\end{array}$ & $\begin{array}{l}\text { Implementation does not follow } \\
\text { from strategic planning } \\
\text { Low maintenance costs } \\
\text { are preferred }\end{array}$ \\
\hline Working culture & $\begin{array}{l}\text { Actions need to be more } \\
\text { supported by investigations, } \\
\text { and tools (financing models) } \\
\text { Mandates needed } \\
+++ \text { Thematic plans } \\
\text { (Gothenburg) }\end{array}$ & $\begin{array}{l}\text { Difficulty to change existing routines or } \\
\text { working culture } \\
\text { Need for learning and collaboration across } \\
\text { sectors } \\
\text { Influences the working culture positively }\end{array}$ & $\begin{array}{l}\text { Actions based on routines, } \\
\text { assumptions and sometimes } \\
\text { fears and mistrust } \\
\text { Implementation deficit } \\
\text { Putting demands on developers } \\
\text { and making it easier to fund } \\
\text { nature-based solutions within } \\
\text { different departments }\end{array}$ \\
\hline Knowledge & $\begin{array}{l}\text { Involving actors in urban } \\
\text { development for knowledge } \\
\text { development }\end{array}$ & $\begin{array}{l}\text { Knowledge needs to increase (e.g., real } \\
\text { estate owners), of importance of urban } \\
\text { development to cope with climate changes } \\
\text { Dialogues for knowledge development was } \\
\text { experienced as a slow process }\end{array}$ & $\begin{array}{l}\text { Real estate owners are not aware } \\
\text { of their responsibilities and } \\
\text { what needs to be done, often } \\
\text { ignoring the issue }\end{array}$ \\
\hline
\end{tabular}




\section{Appendix D}

Table A9. Interpreting error detection and correction into three types of learning barriers.

\begin{tabular}{|c|c|c|c|c|}
\hline \multirow{2}{*}{ Social Learning Phase } & \multirow{2}{*}{ Example } & \multicolumn{3}{|c|}{ Main Type of Learning Barrier } \\
\hline & & Systemic & Opacity & Process \\
\hline \multirow{4}{*}{$\begin{array}{l}\text { Error detection } \\
\text { (Section } 4.1 \text { ) }\end{array}$} & Planning at too small level (Section 4.1.1) & $\mathrm{x}$ & & \\
\hline & Only valuation a small part of the ecosystem (Section 4.1.2) & $\mathrm{x}$ & $\mathrm{x}$ & \\
\hline & Densification mantra affecting error detection (Section 4.1.3) & $\mathrm{x}$ & $\mathrm{x}$ & $\mathrm{x}$ \\
\hline & Knowledge-building barriers (Section 4.1.4) & $\mathrm{x}$ & $\mathrm{x}$ & \\
\hline \multirow[t]{3}{*}{$\begin{array}{l}\text { Error correction } \\
\text { (Section } 4.2 \text { ) }\end{array}$} & Densification mantra (Section 4.2.1) & $\mathrm{x}$ & $\mathrm{x}$ & $\mathrm{x}$ \\
\hline & Unresolved goal conflicts (Section 4.2.2) & $\mathrm{x}$ & $\mathrm{x}$ & \\
\hline & Lack of legislation (Section 4.2.3) & $\mathrm{x}$ & & \\
\hline \multirow[t]{3}{*}{$\begin{array}{l}\text { Receptiveness to error } \\
\text { detection (Section 4.3) }\end{array}$} & Siloed organizations at city level (Section 4.3.1) & $\mathrm{x}$ & $\mathrm{x}$ & $\mathrm{x}$ \\
\hline & Missing leadership and organization (Section 4.3.2) & $\mathrm{x}$ & $\mathrm{x}$ & \\
\hline & Not understanding implementation (Section 4.4.1) & $\mathrm{x}$ & & \\
\hline \multirow{2}{*}{$\begin{array}{l}\text { Responsiveness to } \\
\text { error correction } \\
\text { (Section } 4.4 \text { ) }\end{array}$} & Difficulty changing routines and working culture (Section 4.4.2) & $\mathrm{x}$ & $\mathrm{x}$ & \\
\hline & City actor knowledge needs (Section 4.4.3) & $\mathrm{x}$ & & \\
\hline
\end{tabular}

\section{Appendix E}

\section{Strategy for Systemic Learning for Urban Water Governance}

A conclusion we draw from this study is that to unlock social learning potential, more systemic thinking is necessary [131], including a revision of the dominant management paradigm (Section 5.3). Therefore, we have reformulated the main empirical findings into a five-point strategy for systemic and transformative learning for urban water governance and management (Figure A1).

A. Systemic error detection

1. Systemic planning and valuation for resilient and sustainable urbanization focusing on systemic costs and benefits in the river basin. Urban development needs to link flood risk in individual development plans to the hydrology of the linked river basin across its urban municipalities. In terms of ecosystem services, a wide range of ecosystem services needs to be valued, where citizen involvement may have a role.

B. Systemic error correction

2. Decision-making on systemic planning and valuation needs in turn to be guided by systemic considerations for urban society. For example, overall societal costs and benefits need to better guide chosen solutions, e.g., through cost-sharing between benefactors. Systemic considerations should help working out key strategic goal conflicts, identifying synergies that should be broadly adopted across sectors.

C. Conditions for systemic error detection and correction

3. Organizational setup creating mandates for collaboration and coordination across silos. This is an approach also promoted by the OECD [46], though how to do it is not so well-known [132]. In this study, organizational policies, established working processes, and different cross-sectoral silos were found to support systemic learning (Section 4.3.1). 
4. Working culture and leadership capable of bridging silos and integrating innovations. Bridging of institutional silos is known to require a joint production of knowledge [55]. This involves setting time to build relationships, learning, and understanding different sector's needs, and build a common knowledge base and trust [133]. It requires leadership and political will $[123,130,134]$.

5. Knowledge co-production between practitioners and academia. Academia can support learning in planning by challenging assumptions and guide innovation and learning processes.

\section{A. Error detection}

1. Systemic planning and valuation
B. Error correction

\section{Systemic policies and financial incentives}

C. Conditions for systemic error detection and correction

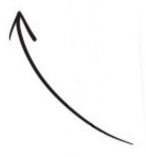

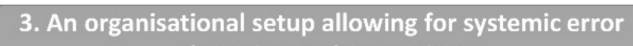

detection and correction

4. Leadership, working processes and culture capable

of integrating systemic approaches in implementation

5. Knowledge development linking academia and

practice

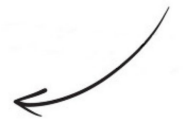

Figure A1. Strategy for systemic and transformative learning for urban water governance and management.

\section{References}

1. Senge, P.M. The Fifth Discipline: The Art E Practice of the Learning Organization; Doubleday Business: New York, NY, USA, 1990.

2. Berkes, F. Environmental governance for the anthropocene? Social-ecological systems, resilience, and collaborative learning. Sustainability 2017, 9, 1232. [CrossRef]

3. United Nations. World Urbanization Prospects, the 2014 Revision; United Nations: New York, NY, USA, 2014.

4. UNDRR, United Nations Office for Disaster Risk Reduction. Global Assessment Report on Disaster Risk Reduction 2019; United Nations: New York, NY, USA, 2019.

5. Maksimović, Č.; Kurian, M.; Ardakanian, R. Rethinking Infrastructure Design for Multi-Use Water Services; Springer Briefs in Environmental Science; Springer International Publishing: New York, NY, USA, 2015.

6. Boström, M.; Andersson, E.; Berg, M.; Gustafsson, K.; Gustavsson, E.; Hysing, E.; Lidskog, R.; Löfmarck, E.; Ojala, M.; Olsson, J.; et al. Conditions for transformative learning for sustainable development: A theoretical review and approach. Sustainability 2018, 10, 4479. [CrossRef]

7. Van Bueren, E.; ten Heuvelhof, E. Improving governance arrangements in support of sustainable cities. Environ. Plan. B Plan. Des. 2005, 32, 47-66. [CrossRef]

8. Pelling, M.; High, C.; Dearing, J.; Smith, D. Shadow spaces for social learning: A relational understanding of adaptive capacity to climate change within organisations. Environ. Plan. A 2008, 40, 867-884. [CrossRef]

9. Pahl-Wostl, C. A conceptual framework for analyzing adaptive capacity and multi-level learning processes in resource governance regimes. Glob. Environ. Chang. 2009, 19, 354-365. [CrossRef]

10. Gerlak, A.K.; Heikkila, T. Tackling key challenges around learning in environmental governance. J. Environ. Policy Plan. 2019, 21, 205-212. [CrossRef]

11. Sörensen, E.; Torfing, J. Enhancing collaborative innovation in the public sector. Adm. Soc. 2011, 43, 842-868. [CrossRef]

12. Qiao, X.; Kristoffersson, A.; Randrup, T.B. Challenges to implementing urban sustainable stormwater management from a governance perspective: A literature review. J. Clean. Prod. 2018, 196, 943-952. [CrossRef] 
13. Cettner, A.; Ashley, R.; Viklander, M.; Nilsson, K. Stormwater management and urban planning: Lessons from 40 years of innovation. J. Environ. Plan. Manag. 2013, 56, 786-801. [CrossRef]

14. Wihlborg, M.; Sörensen, J.; Alkan Olsson, J. Assessment of barriers and drivers for implementation of blue-green solutions in Swedish municipalities. J. Environ. Manag. 2019, 233, 706-718. [CrossRef]

15. Dryzek, J.S. The Politics of the Earth. Environmental Discourses, 3rd ed.; Oxford University Press: Oxford, UK, 2013.

16. Brown, R.R.; Farrelly, M.A. Delivering sustainable urban water management: A review of the hurdles we face. Water Sci. Technol. 2009, 59, 839-846. [CrossRef] [PubMed]

17. Roy, A.H.; Wenger, S.J.; Fletcher, T.D.; Walsh, C.J.; Ladson, A.R.; Shuster, W.D.; Thurston, H.W.; Brown, R.R. Impediments and solutions to sustainable, watershed-scale urban stormwater management: Lessons from Australia and the United States. Environ. Manag. 2008, 42, 344-359. [CrossRef] [PubMed]

18. Mankad, A.; Walton, A.; Alexander, K. Key dimensions of public acceptance for managed aquifer recharge of urban stormwater. J. Clean. Prod. 2015, 89, 214-223. [CrossRef]

19. Rodela, R.; Gerger Swartling, Å. Environmental governance in an increasingly complex world: Reflections on transdisciplinary collaborations for knowledge coproduction and learning. Environ. Policy Gov. 2019, 29, 83-86. [CrossRef]

20. Johannessen, Å.; Gerger Swartling, Å.; Wamsler, C.; Andersson, K.; Arran, J.T.; Hernández Vivas, D.I.; Stenström, T.A. Transforming urban water governance through social (triple-loop) learning. Environ. Policy Gov. 2019, 29, 144-154. [CrossRef]

21. Gonzales-Iwanciw, J.; Dewulf, A.; Karlsson-Vinkhuyzen, S. Learning in multi-level governance of adaptation to climate change-A literature review. J. Environ. Plan. Manag. 2019, 63, 779-797. [CrossRef]

22. Ensor, J.; Harvey, B. Social learning and climate change adaptation: Evidence for international development practice. WIREs Clim. Chang. 2015, 6, 509-522. [CrossRef]

23. Medema, W.; Wals, A.; Adamowski, J. Multi-loop social learning for sustainable land and water governance: Towards a research agenda on the potential of virtual learning platforms. NJAS Wagening. J. Life Sci. 2014, 69, 23-38. [CrossRef]

24. Reed, M.S.; Evely, A.C.; Cundill, G.; Fazey, I.; Glass, J.; Laing, A.; Newig, J.; Parrish, B.; Prell, C.; Raymond, C.; et al. What is social learning? Ecol. Soc. 2010, 15, 1-10. [CrossRef]

25. Tosey, P.; Visser, M.; Saunders, M.N.K. The origins and conceptualizations of "triple-loop" learning: A critical review. Manag. Learn. 2011, 43, 291-307. [CrossRef]

26. Hargrove, R. Masterful Coaching; Jossey Bass/Pfeiffer, Wiley: San Francisco, CA, USA, 2002.

27. Newig, J.; Jager, N.W.; Kochskämper, E.; Challies, E. Learning in participatory environmental governance-Its antecedents and effects. Findings from a case survey meta-analysis. J. Environ. Policy Plan. 2019, 21, $213-227$. [CrossRef]

28. Van Buuren, A. Knowledge for water governance: Trends, limits, and challenges. Int. J. Water Gov. 2013, 1, 157-175. [CrossRef]

29. Næss, P.; Saglie, I.L.; Richardson, T. Urban sustainability: Is densification sufficient? Eur. Plan. Stud. 2019, 28, 146-165. [CrossRef]

30. McDonald, R.I.; Weber, K.; Padowski, J.; Flörke, M.; Schneider, C.; Green, P.A.; Gleeson, T.; Eckman, S.; Lehner, B.; Balk, D.; et al. Water on an urban planet: Urbanization and the reach of urban water infrastructure. Glob. Environ. Chang. 2014, 27, 96-105. [CrossRef]

31. Arundel, J.; Lowe, M.; Hooper, P.; Roberts, R.; Rozek, J.; Higgs, C.; Giles-Corti, B. Creating Liveable Cities in Australia: Mapping Urban Policy Implementation and Evidence-Based National Liveability Indicators; Centre for Urban Research: Melbourne, Australia, 2017.

32. Neuman, M. The compact city fallacy. J. Plan. Educ. Res. 2005, 25, 11-26. [CrossRef]

33. Aram, F.; Higueras García, E.; Solgi, E.; Mansournia, S. Urban green space cooling effect in cities. Heliyon 2019, 5, e01339. [CrossRef]

34. Elmqvist, T.; Setälä, H.; Handel, S.N.; van der Ploeg, S.; Aronson, J.; Blignaut, J.N.; Gómez-Baggethun, E.; Nowak, D.J.; Kronenberg, J.; de Groot, R. Benefits of restoring ecosystem services in urban areas. Curr. Opin. Environ. Sustain. 2015, 14, 101-108. [CrossRef]

35. Brudler, S.; Arnbjerg-Nielsen, K.; Hauschild, M.Z.; Rygaard, M. Life cycle assessment of stormwater management in the context of climate change adaptation. Water Res. 2016, 106, 394-404. [CrossRef]

36. Dhakal, K.P.; Chevalier, L.R. Managing urban stormwater for urban sustainability: Barriers and policy solutions for green infrastructure application. J. Environ. Manag. 2017, 203, 171-181. [CrossRef] 
37. Voskamp, I.M.; Van de Ven, F.H.M. Planning support system for climate adaptation: Composing effective sets of blue-green measures to reduce urban vulnerability to extreme weather events. Build. Environ. 2015, 83, 159-167. [CrossRef]

38. Ostrom, E.A. General framework for analyzing sustainability of social-ecological systems. Science 2009, 325, 419-422. [CrossRef] [PubMed]

39. Gray, B. Collaborating: Finding Common Ground for Multiparty Problems; Jossey-Bass: San Francisco, CA, USA, 1989.

40. Hersperger, A.M.; Oliveira, E.; Pagliarin, S.; Palka, G.; Verburg, P.; Bolliger, J.; Grădinaru, S. Urban land-use change: The role of strategic spatial planning. Glob. Environ. Chang. 2018, 51, 32-42. [CrossRef]

41. Patterson, J.; Smith, J.C.; Bellamy, J. Understanding enabling capacities for managing the 'wicked problem' of nonpoint source water pollution in catchments: A conceptual framework. J. Environ. Manag. 2013, 128, 441-452. [CrossRef] [PubMed]

42. Johannessen, Å.; Hahn, T. Social learning towards a more adaptive paradigm? Reducing flood risk in Kristianstad municipality, Sweden. Glob. Environ. Chang. 2013, 23, 372-381. [CrossRef]

43. Von Schönfeld, K.C.; Tan, W.; Wiekens, C.; Salet, W.; Janssen-Jansen, L. Social learning as an analytical lens for co-creative planning. Eur. Plan. Stud. 2019, 27, 1291-1313. [CrossRef]

44. Georgiadis, T.; Iglesias, A.; Iglesias, P. City resilience to climate change. In Rooftop Urban Agriculture; Orsini, F., Dubbeling, M., de Zeeuw, H., Gianquinto, G., Eds.; Springer: Cham, Switzerland, 2017; pp. 253-262.

45. Brondizio, E.S.; O’Brien, K.; Bai, X.; Biermann, F.; Steffen, W.; Berkhout, F.; Cudennec, C.; Lemos, M.C.; Wolfe, A.P.; Palma-Oliveira, J.; et al. Reconceptualizing the anthropocene: A call for collaboration. Glob. Environ. Chang. 2016, 39, 318-327. [CrossRef]

46. OECD Organisation for Economic Co-operation and Development. OECD Systems Approaches to Public Sector Challenges: Working with Change; OECD Publishing: Paris, France, 2017.

47. Patterson, J.; de Voogt, L.D.; Sapiains, R. Beyond inputs and outputs: Process-oriented explanation of institutional change in climate adaptation governance. Environ. Policy Gov. 2019, 29, 360-375. [CrossRef]

48. Blackmore, C.; van Bommel, S.; de Bruin, A.; de Vries, J.R.; Westberg, L.; Powell, N.; Foster, N.; Collins, K.; Roggero, P.P.; Seddaiu, G. Learning for transformation of water governance (CADWAGO) project. Water 2016, 8, 510. [CrossRef]

49. Armitage, D.; Marschke, M.; Plummer, R. Adaptive co-management and the paradox of learning. Glob. Environ. Chang. 2008, 18, 86-98. [CrossRef]

50. Argyris, C. Single-loop and double-loop models in research on decision making. Adm. Sci. Q. 1976, 21, 363-375. [CrossRef]

51. Argyris, C. Double loop learning in organisations. Harv. Bus. Rev. 1977, 115-124.

52. Argyris, C. On Organizational Learning, 2nd ed.; Blackwell: Oxford, UK, 1999.

53. Argyris, C.; Schön, D. Organizational Learning: A Theory of Action Perspective; Addison-Wesley: Reading, MA, USA, 1978.

54. Argyris, C.; Schön, D.A. Organizational Learning II-Theory, Method, and Practice; Addison-Wesley: Reading, MA, USA, 1996.

55. Daniels, S.E.; Walker, G.B. Working through Environmental Conflict: The Collaborative Learning Approach; Praeger: Westport, WA, USA, 2001.

56. Oliver, P.; Marwell, G.; Teixeira, R. A theory of the critical mass. I. interdependence, group heterogeneity, and the production of collective action. Am. J. Sociol. 1985, 91, 522-556. [CrossRef]

57. Jagers, S.C.; Harring, N.; Lofgren, A.; Sjostedt, M.; Alpizar, F.; Brulde, B.; Langlet, D.; Nilsson, A.; Almroth, B.C.; Dupont, S.; et al. On the preconditions for large-scale collective action. AMBIO 2020, 49, 1282-1296. [CrossRef] [PubMed]

58. Olson, M. The Logic of Collective Action; Harvard University Press: Cambridge, MA, USA, 1965.

59. Holling, C.S. Adaptive Environmental Assessment and Management; Wiley: New York, NY, USA, 1978.

60. Walters, C.J. Adaptive Management of Renewable Resources; McGraw Hill: New York, NY, USA, 1986.

61. Lee, K. Compass and Gyroscope: Integrating Science and Politics for the Environment; Island Press: Washington, DC, USA, 1993.

62. Pahl-Wostl, C.; Sendzimir, J.; Jeffrey, P.; Aerts, J.; Bergkamp, G.; Cross, K. Managing change toward adaptive water management through social learning. Ecol. Soc. 2007, 2, 30. [CrossRef] 
63. Scrieciu, S.S.; Barker, T.; Ackerman, F. Pushing the boundaries of climate economics: Critical issues to consider in climate policy analysis. Ecol. Econ. 2011, 85, 155-165. [CrossRef]

64. Morais-Storz, M.; Nguyen, N. The role of unlearning in metamorphosis and strategic resilience. Learn. Organ. 2017, 24, 93-106. [CrossRef]

65. Sent, E.M.; Klaes, M. A conceptual history of the emergence of bounded rationality. Hist. Political Econ. 2005, 37, 27-59. [CrossRef]

66. Gerlak, A.K.; Heikkila, T. Building a Theory of Learning in Collaboratives: Evidence from the Everglades Restoration Program. J. Public Adm. Res. Theory 2011, 21, 619-644. [CrossRef]

67. Romme, A.G.L.; van Witteloostuijn, A. Circular organizing and triple loop learning. J. Organ. Chang. Manag. 1999, 12, 439-453. [CrossRef]

68. Crossan, M.M.; Lane, H.W.; White, R.E. An organizational learning framework: From intuition to institution source. Acad. Manag. Rev. 1999, 24, 522-537. [CrossRef]

69. Kolb, D. Experiential Learning as the Science of Learning and Development; Prentice Hall: Englewood Cliffs, NJ, USA, 1984.

70. Flood, R.L.; Romm, N.R.A. Plurality revisited: Diversity management and triple loop learning. Syst. Pract. 1996, 9, 587-603. [CrossRef]

71. Dryzek, J.S. Deliberative Democracy and Beyond: Liberals, Critics, Contestations; Oxford University Press: Oxford, UK, 2000.

72. Meadows, D.H. Thinking in Systems-A Primer; Sustainability Institute, Chelsea Green Publishing: White River Junction, VT, USA, 2008.

73. Moser, S.C.; Ekstrom, J.A. A framework to diagnose barriers to climate change adaptation. Proc. Natl. Acad. Sci. USA 2010, 107, 22026-22031. [CrossRef] [PubMed]

74. Rodela, R. The social learning discourse: Trends, themes and interdisciplinary influences in current research. Environ. Sci. Policy 2013, 25, 157-166. [CrossRef]

75. Fidel, R. The case study method: A case study. Libr. Inf. Sci. Res. 1984, 6, 273-288.

76. Eisenhardt, K.M. Better stories and better constructs: The case for rigor and comparative logic. Acad. Manag. Rev. 1991, 16, 620-627. [CrossRef]

77. Brinkmann, S.; Kvale, S. InterViews: Learning the Craft of Qualitative Research Interviewing; Sage: Thousand Oaks, CA, USA, 2015.

78. Wendling, Z.A.; Emerson, J.W.; Esty, D.C.; Levy, M.A.; de Sherbinin, A.; Spiegel, N.R.; Pinkerton, V.; Boucher, L.; Ratté, S.; Mardell, S.; et al. 2018 Environmental Performance Index; Yale Center for Environmental Law \& Policy: New Haven, CT, USA, 2018; Available online: https:/epi.envirocenter.yale.edu/downloads/ epi2018reportv06191901.pdf (accessed on 24 August 2020).

79. Flyvbjerg, B. Five Misunderstandings about Case-Study Research. Qual. Inq. 2006, 12, 219-245. [CrossRef]

80. Bernard, H.R. Research Methods in Anthropology-Qualitative and Quantitative Approaches; Altamira Press: Walnut Creek, CA, USA, 2002.

81. Glaser, B.G. Theoretical Sensitivity: Advances in the Methodology of Grounded Theory; Sociology Press: Mill Valley, CA, USA, 1978.

82. Urquhart, C. Grounded Theory for Qualitative Research: A Practical Guide; Sage Publications Inc.: London, UK, 2013.

83. Bowen, G.A. Document analysis as a qualitative research method. Qual. Res. J. 2009, 9, 27-40. [CrossRef]

84. SCB (Statistics Sweden). Folkmängd, Topp 50 Dec 2019. [Population, Top 50]. Available online: http://www.scb.se/hitta-statistik/statistik-efter-amne/befolkning/befolkningens-sammansattning/ befolkningsstatistik/pong/tabell-och-diagram/topplistor-kommuner/folkmangd-topp-50/ (accessed on 22 June 2020).

85. Ogundbode, C.; Demski, C.; Capstick, S.B.; Sposato, R.G. Attribution matters: Revisiting the link between extreme weather experience and climate change mitigation responses. Glob. Environ. Chang. 2019, 54, 31-39. [CrossRef]

86. Boverket. Reviderad Prognos över Behovet av nya Bostäder Till 2025. [Revised Forecast for the Need for New Housing in 2025]; Report No. 2016:18; Swedish National Board of Housing, Building and Planning: Karlskrona, Sweden, 2016. 
87. City of Gothenburg. Översiktsplan för Göteborg Antagen av Kommunstyrelsen 2009-02-26. Stadsbyggnadskontoret. [Comprehensive Plan for Gothenburg-Adopted by the City Council 2009-02-26. The city Planning Authority]; City of Gothenburg: Gothenburg, Sweden, 2009.

88. City of Malmö. Översiktsplan för Malmö. [Comprehensive Plan for Malmö]; Stadsbyggnadskontoret i Malmö: Malmö, Sweden, 2018.

89. Andersson-Sköld, Y.; Klingberg, J.; Gunnarsson, B.; Cullinane, K.; Gustafsson, I.; Hedblom, M.; Knez, I.; Lindberg, F.; Ode Sang, Å.; Pleijel, H.; et al. A framework for assessing urban greenery's effects and valuing its ecosystem services. J. Environ. Manag. 2018, 205, 274-285. [CrossRef]

90. Read, K.E.; Karras, M.; Sörensen, J.; Cedergren, A. Kostnads-nyttoanalys av införandet av hållbar dagvattenhantering som riskreducerande åtgärd mot översvämning-Med fokus på monetär värdering av ekosystemtjänster [Cost-benefit analysis of sustainable drainage system as flood risk reduction measure]. VATTEN J. Water Manag. Res. 2016, 72, 159-168.

91. SCB (Statistics Sweden). Green space and green areas within localities 2010. In Statistiska Meddelanden; MI 12 SM 1501; SCB (Statistics Sweden): Stockholm, Sweden, 2015; p. 35. ISSN 1403-8978. (In Swedish with an English Summary).

92. SFS. Plan- och Bygglag (2010:900) [Planning and Building Act]; (2010:900), Svensk författningssamling: Stockholm, Sweden, 2010.

93. Joos, A. Åtgärder för Att Möta en Förhöjd Havsnivå-En Jämförelse av Översvämningshantering $i$ Göteborg och Malmö. [Measures to Meet a Sea Level Rise-A Comparison of Flood Management in Gothenburg and Malmö]; SLU, Sveriges lantbruksuniversitet: Uppsala, Sweden, 2019.

94. Stahre, P. Blue-Green Fingerprints in the City of Malmö: Malmö's Way to a Sustainable Urban Drainage; VA Syd: Malmö, Sweden, 2008.

95. Haghighatafshar, S.; la Cour Jansen, J.; Aspegren, H.; Lidström, V.; Mattsson, A.; Jönsson, K. Storm-water management in Malmö and Copenhagen with regard to climate change scenarios. J. Water Manag. Res. 2014, 70, 159-168.

96. Theland, J. Funktionen av Hållbara Dagvattenlösningar och Gröna Ytor vid Extrema Regn-En Analys Baserad på Översvämningarna i Malmö den 31 Augusti 2014. [Function of SUDS and Green Surfaces at Extreme Rainfall-An Analysis of the Floods in Malmö on the 31 Aug 2014]; Examensarbete TVVR 15/5003; Avdelningen för Teknisk Vattenresurslära, Institutionen för Bygg- och Miljöteknologi, Lunds Universitet: Lund, Sweden, 2015.

97. Länsstyrelsen i Stockholms Län och Länsstyrelsen i Västra Götalands län. Rekommendationer för Hantering av Översvämning Till Följd av Skyfall—Stöd i Fysisk Planering. [Recommendations for Managing Floods Caused by Extreme Rainfall—Support to Spatial Planning]; The County Administrative Boards of Stockholm and Västra Götaland: Stockholm, Sweden, 2018; p. 5.

98. Boverket. Tillsynsvägledning Avseende Översvämningsrisker; Rapport 2018:8; Boverket: Karlskrona, Sweden, 2018; p. 28.

99. Cullberg, M.; Montin, S.; Tahvlizadeh, N. Urban Challenges, Policy and Action in Gothenburg: GAPS Project Baseline Study; Mistra Urban Futures Reports 2014:5; Mistra Urban Futures: Gothenburg, Sweden, 2014.

100. Rain Gothenburg. Available online: http://www.goteborg2021.com/jubileumsprojekt/rain-gothenburg/ (accessed on 22 June 2020).

101. Jennische, A. Göteborg först med Skyfallsplan. Byggindustrin, 26 June 2019. Available online: https: //byggindustrin.se/artikel/nyhet/goteborg-forst-med-skyfallsplan-28420 (accessed on 22 June 2020).

102. City of Malmö. Malmös Vatten-Kunskaps- och Planeringsunderlag. [Malmö's Waters-Knowledge and Planning Background]; Malmö Stad/City of Malmö: Malmö, Sweden, 2018.

103. City of Gothenburg. Grönytefaktorer i Plan och Exploateringsprojekt i Göteborgs Stad. [Green Area Factor in Plan and Development Projects in the City of Gothenburg]; Göteborgs stad/City of Gothenburg: Gothenburg, Sweden, 2018. Available online: https://goteborg.se/wps/portal?uri=gbglnk\%3agbg.page.1d060bfd-fab8--408f-880e2758fb3bee32 (accessed on 22 June 2020).

104. Delshammar, T.; Falck, M. Grönytefaktorn i Sverige. [The Green Area Factor in Sweden]; Rapport 2014: 21; Fakulteten för landskapsarkitektur, trädgårds- och växtproduktionsvetenskap, Sveriges lantbruksuniversitet: Alnarp, Sweden, 2014.

105. Memborn, L.; Westerlund, J. Historisk Stadsplaneanalys för Göteborgs Stad: En Högupplöst Stadsplan. [Historical City Plan Analysis for the City of Gothenburg]. 2017. Available online: https://gbg.yimby.se/2017/ 11/historisk-stadsplaneanaly_3999.html (accessed on 22 June 2020). 
106. Miljöbyggprogram SYD. Available online: http://www.miljobyggprogramsyd.se/ (accessed on 22 June 2020).

107. Sabatier, P.; Mazmanian, D. The implementation of public policy: A framework of analysis. Policy Stud. J. 1980, 8, 538-560. [CrossRef]

108. Mohr, L.B. The implications of effectiveness theory for managerial practice in the public sector. In Organizational Effectiveness; Cameron, K.S., Whetten, D.A., Eds.; Academic Press: New York, NY, USA, 1983; pp. 225-239.

109. Government Bill. Regeringens Proposition 2017/18:163. Nationell Strategi för Klimatanpassning; Government Offices of Sweden: Stockholm, Sweden, 2017.

110. Mosley, S. A disaster in slow motion, the smoke menace in urban-industrial Britain. In Learning and Calamities. Practices, Interpretations, Patterns; Egner, H., Schorch, M., Voss, M., Eds.; Routledge studies in environment, culture and society; Taylor \& Francis: New York, NY, USA; London, UK, 2015; pp. 94-111.

111. Kahneman, D.; Frederick, S. Representativeness Revisited: Attribute Substitution in Intuitive Judgment. In Heuristics and Biases: The Psychology of Intuitive Judgment; Gilovich, T., Griffin, D.W., Kahneman, D., Eds.; Cambridge University Press: Cambridge, UK, 2002; pp. 51-52.

112. Kingdon, J.W. Agendas Alternatives, and Public Policies; Pearson New International Edition; Pearson: Harlow, UK, 2014.

113. Moyson, S.; Scholten, P.; Weible, C.M. Policy learning and policy change: Theorizing their relations from different perspectives. Policy Soc. 2017, 36, 161-177. [CrossRef]

114. Kitur, R.C. Barriers to Implementing Urban Plans in Kenya. Ph.D. Thesis, Walden University, Minneapolis, MN, USA, 2019. Available online: https://scholarworks.waldenu.edu/cgi/viewcontent.cgi? article $=8512 \&$ context=dissertations (accessed on 31 July 2020).

115. Kenawy, E.; Osman, T.; Alshamndy, A. What Are the Main Challenges Impeding Implementation of the Spatial Plans in Egypt Using Ecotourism Development as an Example? Soc. Sci. 2017, 6, 75. [CrossRef]

116. Schmidt, V.A. Speaking of change: Why discourse is key to dynamics of policy transformation. Crit. Policy Stud. 2011, 5, 106-126. [CrossRef]

117. Baumgartner, F.; Jones, B. Agendas and Instability in American Politics; University of Chicago Press: Chicago, IL, USA, 1993.

118. Baumgartner, F.R.; Breunig, C.; Green-Pedersen, C.; Jones, B.D.; Mortensen, P.B.; Nuytemans, M.; Walgrave, S. Punctuated Equilibrium in Comparative Perspective. Am. J. Political Sci. 2009, 53, 603-620. [CrossRef]

119. Flink, C.M. Rethinking Punctuated Equilibrium Theory: A Public Administration Approach to Budgetary Changes. Policy Stud. J. 2017, 45, 101-120. [CrossRef]

120. Argyris, C.; Schön, D.A. Theory in Practice: Increasing Professional Effectiveness; Jossey-Bass: San Francisco, CA, USA, 1974.

121. March, J.G. Exploration and exploitation in organizational learning source. Organ. Sci. 1991, 2, 71-87. [CrossRef]

122. Gieske, H.; Duijn, M.; van Buuren, A. Ambidextrous practices in public service organizations: Innovation and optimization tensions in Dutch water authorities. Public Manag. Rev. 2020, 22, 341-363. [CrossRef]

123. Huber, G.P. Organizational learning: The contributing processes and the literatures. Organ. Sci. 1991, 2, 88-115. [CrossRef]

124. Von Bertalanffy, L. General System Theory—Foundations, Development, Applications; George Braziller: New York, NY, USA, 1968.

125. Easton, D. The Political System: An Inquiry into the State of Political Science; Alfred A Knopf: New York, NY, USA, 1953.

126. Checkland, P. Systems thinking and management theory. Am. Behav. Sci. 1994, 38, 75-91. [CrossRef]

127. Stewart, J.; Ayres, R. Systems theory and policy practice: An exploration. Policy Sci. 2001, 34, 79-94. [CrossRef]

128. Van de Walle, S.; Hammerschmid, G. The impact of the new public management: Challenges for coordination and cohesion in European public sectors (review essay). Halduskultuur Adm. Cult. 2011, 12, 190-209.

129. Hammerschmid, G.; Van de Walle, S.; Andrews, R.; Mostafa, A.M.S. New Public Management reforms in Europe and their effects: Findings from a 20-country top executive survey. Int. Rev. Adm. Sci. 2018, 85, 399-418. [CrossRef]

130. Oseland, S.E. Breaking silos: Can cities break down institutional barriers in climate planning? J. Environ. Policy Plan. 2019, 21, 345-357. [CrossRef]

131. Wilson, R.S.; Herziger, A.; Hamilton, M.; Brooks, J.S. From incremental to transformative adaptation in individual responses to climate-exacerbated hazards. Nat. Clim. Chang. 2020, 10, 200-208. [CrossRef] 
132. Crawford Urban, M. Abandoning Silos-How Innovative Governments are Collaborating Horizontally to Solve Complex Problems; Mowat research \#178; Mowat Centre, University of Toronto: Toronto, ON, Canada, 2018. Available online: https://munkschool.utoronto.ca/mowatcentre/wp-content/uploads/publications/178_ abandoning_silos.pdf (accessed on 22 June 2020).

133. Jacobs, K.; Lebel, L.; Buizer, J.; Addams, L.; Matson, P.; McCullough, E.; Garden, P.; Saliba, G.; Finan, T. Linking knowledge with action in the pursuit of sustainable water-resources management. Proc. Natl. Acad. Sci. USA 2016, 113, 4591-4596. [CrossRef]

134. Carter, J.G.; Cavan, G.; Connelly, A.; Guy, S.; Handley, J.; Kazmierczak, A. Climate change and the city: Building capacity for urban adaptation. Prog. Plan. 2015, 95, 1-66. [CrossRef]

(C) 2020 by the authors. Licensee MDPI, Basel, Switzerland. This article is an open access article distributed under the terms and conditions of the Creative Commons Attribution (CC BY) license (http://creativecommons.org/licenses/by/4.0/). 